\title{
The Relationship between the Flow Properties of Clay Slurry Samples and the Properties of Ceramic Green/Sintered Products
}

\author{
Sedef Dikmen ${ }^{1 *}$, Tuğba Mucur ${ }^{2}$, Zeyni Arsoy ${ }^{3}$, Bahri Ersoy $^{4}$ \\ 1*Eskişehir Technical University, Faculty of Science, Department of Physics, Eskişehir, Turkey, (ORCID: 0000-0002-6164-4710), sdikmen@eskisehir.edu.tr \\ ${ }^{2}$ Ankara Seramic A.Ş, R\&D Center, Ankara, Turkey, (ORCID: 0000-0000-0000-0000), tubamucur@gmail.com \\ ${ }^{3}$ Afyon Kocatepe University, Faculty of Engineering, Department of Mining, Afyonkarahisar, Turkey, (ORCID: 0000-0001-5694-6338), zeyniarsoy@aku.edu.tr \\ ${ }^{4}$ Afyon Kocatepe University, Faculty of Engineering, Department of Mining, Afyonkarahisar, Turkey, (ORCID: 0000-0002-0075-9039), bersoy@aku.edu.tr
}

(First received 15 June 2020 and in final form 14 October 2020)

(DOI: 10.31590/ejosat.752832)

ATIF/REFERENCE: Dikmen, S., Mucur, T., Arsoy, Z. \& Ersoy, B. (2020). The Relationship between the Flow Properties of Clay Slurry Samples and the Properties of Ceramic Green/Sintered Products. European Journal of Science and Technology, (20), 233-247.

\begin{abstract}

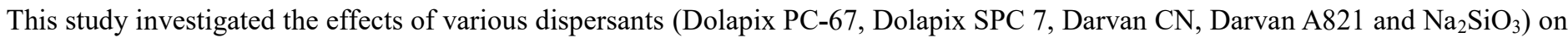
the flow properties of slurry prepared using ESC-3 clay to find the optimum dispersant type and dispersant dosage to produce the required properties in green and sintered products produced by slip casting. By considering the flow curves of slurry, it was determined that the most suitable dispersant was Dolapix PC-67 and the dosage was $\sim 0.1 \%$. Afterwards, the slurry was prepared in bar-shaped samples keeping the same experimental conditions and using Dolapix PC-67 dosages of 0, 0.03, 0.1 and $1.0 \mathrm{wt}$. \%. The resulting green body samples were dried and sintered at $1200^{\circ} \mathrm{C}$. Some physico-mechanical tests were applied to both the green and sintered samples, as well as investigating their microstructure, crystallinity and secondary phase formations using SEM and XRD. Some of the results obtained were as follows: (i) adding dispersant to the slurry had a positive effect on the physical and mechanical properties of the green and sintered products obtained by slip casting. (ii) Determination of the optimum dispersant dosage used in the ceramic slurry by slip casting is an important factor. When the properties of the green/final products and their flow curves measured by Ford cup were considered, it can be said that the dispersant dosage at which the shortest flow duration was obtained did not always correspond to the best results for the physico-mechanical properties of green/final products. (iii) The relationship between the green and sintered samples prepared from slip casting using different dispersant dosages, and the flow curves of these slips, could not be observed from their SEM images.
\end{abstract}

Keywords: Slip casting, Clay slurry, Dispersant, Flow time, Green/sintered product, Physico-mechanical properties.

\section{Kil Çamuru Örneklerinin Akış Özellikleri ile Seramik Ham/Pişmiş Ürünlerin Özellikleri Arasındaki İlişki}

$\ddot{O} z$

$\mathrm{Bu}$ çalışmada, slip döküm ile üretilen ham ve sinterlenmiş ürünlerde istenilen özellikleri sağlamak için ESC-3 kili kullanılarak hazırlanan çamura çeşitli dispersantların (Dolapix PC-67, Dolapix SPC 7, Darvan CN, Darvan A821 ve Na $\mathrm{NiO}_{3}$ ), akış özelliklerine etkileri araştırıldı. Çamurun akış eğrileri dikkate alınarak, en uygun dispersantın Dolapix PC-67 olduğu ve dozajın da $\sim \% 0.1$ olduğu belirlendi. Daha sonra çamur, aynı deney şartlarında ve sırasıyla ağırlıkça \% 0, 0.03, 0.1 ve 1.0 Dolapix PC-67 dozajları kullanılarak çubuk şeklindeki numuneler hazırlandı. Elde edilen ham numuneler kurutulduktan sonra $1200^{\circ} \mathrm{C}^{\prime} \mathrm{de}$ sinterlendi. Ham ve sinterlenmiş numunelere bazı fiziksel ve mekanik testler uygulanmış, ayrıca SEM ve XRD kullanılarak mikro yapıları, kristallikleri ve ikincil faz oluşumları incelenmiştir. Elde edilen sonuçlardan bazıları şöyledir: (i) Çamura dispersant ilave edilmesi, slip döküm ile elde edilen ham

* Corresponding Author: sdikmen@eskisehir.edu.tr 
ve sinterlenmiş ürünlerin fiziksel ve mekanik özellikleri üzerinde olumlu bir etkiye sahip olmuştur. (ii)Slip döküm yöntemiyle kil çamuru hazırlanırken kullanılacak dispersant miktarının optimum değerinin belirlenmesi önemli bir husustur. Ancak ford cup ile elde edilen akışkanlık eğrileri ve sonrasında elde edilen ham/sinterlenmiş ürün özelliklerine göre şu söylenebilir: Seramik döküm çamurlarında akış süresinin en düşük (yani akışkanlığın en yüksek) olduğu dispersant dozajında, ham ve sinterlenmiş ürünlerin fiziksel/mekanik özelliklerinin de daima en iyi olacağı anlamına gelmemektedir. (iii) Farklı dispersant dozajlarında hazırlanan çamurdan elde edilen ham ve pişmiş ürünlerin fiziksel ve mekanik özellikleri ile çamurun akışkanlık eğrisi arasındaki ilişkiyi SEM görüntüleriyle ortaya koymak pek mümkün değildir.

Anahtar Kelimeler: Slip döküm, Kil çamuru, Dispersant, Akış süresi, Ham/sinterlenmiş ürün, Fiziko-mekanik özellikler.

\section{Introduction}

Slip casting is a forming method used to produce both conventional and technical ceramic products. Compared to some forming methods, such as dry pressing and extrusion, slip casting has important advantages that enable it to produce complexshaped products; it is simple and economical and also achieves a more homogeneous green body [1-7]. One of the most important conditions to produce a fired product with the desired properties by using the slip casting method is to obtain a green body with high green density. This depends on the preparation of a stable and homogeneous suspension or slurry with appropriate rheological properties. Thus, ceramic powders in suspension will be closely packed on a plaster mould surface to obtain homogeneous green bodies with a high green density [8]. Easy and smooth forming depends on the preparation of flowing suspensions with higher packing density, suitable stability and fluidity. This can only be achieved by using various chemical additives called dispersants [1,9-11]. Dispersants are used to determine the rheological properties by increasing the packing density of the slurry that significantly reduces the amount of water required for fluidity and prevents the tendency of particles to agglomerate. Therefore, a closely packed structure with high green density achieved the formation of a stable microstructure without cracking and fragmentation during the firing process [ 1 , $2,12,13]$. Moreover, it is very important to determine the slip casting conditions, i.e., the flow behavior that governs the microstructure, by adjusting the type and amount of electrolyte additives used for the suspension and also for forming advanced technology ceramics using this method. The parameters affecting the fluidity of solid suspensions (slurries) can be categorized into three basic groups $[10,14]$ :

(i) Parameters based on solid properties (solid ratio, particle size distribution, surface area, particle shape, etc.)

(ii) Parameters based on medium (fluid type, temperature and viscosity, etc.)

(iii) The interaction between particles (electrostatic, steric repulsion and Van der Waals repulsion forces) is related to the type and amount of dispersant used to prepare suspensions or slurries.

Numerous studies have been carried out to examine the effect of various inorganic and organic dispersants on the viscosity of ceramic casting slurries [14-22]. However, in published literature, there are a limited number of studies investigating the effect of the dispersion conditions of ceramic slurries on its slip casting behavior and on the resulting properties of green/fired products. Few studies have been conducted examining the slip casting behavior of clay slurry and the properties of green/fired products $[21,23]$. The number of studies concentrating on some advanced ceramic powders like alumina [3], cordierite [14], mullite powders [23], mullite-zirconia [24], cordierite-mullite [25], and cordierite-based glass-ceramic $[4,27]$ is much higher.
Eygi and Ateşok (2008) [21] used three different types of commercial kaolin, namely ESK-410 (Ukraine), CC-31 (England) and K-2 (Bulgaria). In that study, it was determined that polyelectrolytes were more effective than sodium silicate in decreasing viscosity and thixotropy, and in increasing the strength of the green body for all three kaolin slurries. It was stated that the most suitable dispersant and the optimum amount was different for each type of kaolin slurry. Optimum dispersant amounts used for $100 \mathrm{~g}$ of kaolin were determined to be $0.65 \mathrm{~mL}$ of Dolapix SPC 7 for ESK-410, 0.45 mL of Aquatreat AR-602-N (sodium polyacrylic acid-based) for $\mathrm{CC}-31$ and $0.70 \mathrm{~mL}$ of Dolapix SPC 7 for K-2, respectively. Moreover, another important result obtained from that study was that the strength of the green body decreased with increasing casting rate. The reason for this was that the packing was neither homogeneous nor close due to the faster casting rate. Accordingly, water rapidly left the structure during drying, forming larger porosities. Tsetsekou et al. (2001) [3] investigated the slip casting behavior of alumina slurry with 80 wt. \% solid ratio in the presence of different dispersants (Darvan C, Duramax D 3005 and Dolapix CE64). It was stated that polycarboxylic Dolapix CE64 was the most suitable dispersant to prepare a slurry with high stability, and the lowest casting rate and highest packing density was achieved with this dispersant resulting in the highest green and fired density. Mei et al. (2001) [26] investigated the slip casting behaviors of slurry prepared using cordierite and glass powder with $60 \mathrm{wt} . \%$ solid ratio in the presence of Dolapix CE64 with different dosages and determined that dispersant dosage had a very important effect on slurry rheology. They stated that the slurry showed Bingham flow at low dosage, while its behavior changed to Newtonian flow with increasing dosage. They determined that when more dispersants were added to the medium than was optimum (the case at the lowest viscosity), the slurry showed time-dependent, shear thickening flow. Moreover, they pointed out that dispersant dosages lower or higher than the optimum value negatively affected the packing and thus the microstructure of the green product. It also increased the porosity. Şakar-Deliormanli and Yayla (2004) [20] investigated the effect of sodium carbonate $\left(\mathrm{NaCO}_{3}\right)$ and calcium hydroxide $\left[\mathrm{Ca}(\mathrm{OH})_{2}\right]$ on the slip casting behavior of sanitary ware slurry (24\% feldspar, 24\% quartz, 35\% kaolin and $25 \%$ ball clay). As a result of the examinations, they determined that the increase in the amount of dispersant did not cause a significant change in thixotropy, and that the thixotropy value varied between 30 and 33 . Based on these results, there was no significant relationship between viscosity and thixotropy. As a result of the slip casting process, they stated that the samples with $\mathrm{Ca}(\mathrm{OH})_{2}$ increased green and fired product strength more than the $\mathrm{NaCO}_{3}$ samples. They also found that the bodies obtained by adding $\mathrm{Ca}(\mathrm{OH})_{2}$ had lower water absorption than those obtained by adding $\mathrm{NaCO}_{3}$.

The present study investigated the effect of various silicate based on sodium silicate $\left(\mathrm{Na}_{2} \mathrm{SiO}_{3}\right)$ and polymer-based dispersants (Dolapix PC-67, Dolapix SPC 7, Darvan CN and Darvan $821 \mathrm{~A}$ ) on the flow behavior of $60 \mathrm{wt} . \%$ solid slurry 
prepared with ESC-3 clay to determine the optimum dispersant and dispersant dosage. Slurries were prepared at four different dispersant dosages and their slip casting behaviors and green/fired product properties were characterized.

\section{Material and Method}

\subsection{Raw Material and Characterization}

Commercial clay, called ESC-3, was purchased from the Eczacıbaşı Esan Company. The major and minor elements in the raw material were analyzed using a Bruker S8 TIGER X-ray fluorescence (XRF) spectrophotometer. The particle size distribution of ESC-3 clay was measured using a Malvern Mastersizer 2000G laser diffractometer. The specific surface area ( $\mathrm{S}_{\mathrm{BET}}$ ) was calculated based on $\mathrm{N}_{2}$ adsorption-desorption curves at $77 \mathrm{~K}$ (Quantachrome, NOVA 1000e instrument). X-ray diffraction (XRD) was performed to determine the mineral composition of the ESC-3 clay. A Shimadzu XRD-6000 diffractometer was used, working at $40 \mathrm{kV} / 25 \mathrm{~mA}$. Thermal analysis that included thermogravimetric (TG) and differential thermal analysis (DTA) was performed using Setaram Setsys Evolution equipment at a heating rate of $5^{\circ} \mathrm{C} / \mathrm{min}$ in a nitrogen atmosphere. Samples weighing 2 to $5 \mathrm{mg}$ were placed in an aluminum crucible and scanned from $25^{\circ} \mathrm{C}$ to $900^{\circ} \mathrm{C}$. The initial and final degradation temperatures, as well as the corresponding weight loss, were recorded. To observe microstructural changes, Scanning Electron Microscopy (SEM) images were taken (Leo 1430 SEM).

\subsection{Dispersants}

Five commercially available polymeric and inorganic dispersants were used for slurry stabilization, known by the commercial names Dolapix SPC 7, Dolapix PC-67 (Zschimmer\&Schwarz, GmbH), Darvan 821A, Darvan CN (Vanderbilt Company, Inc) and sodium silicate $\left(\mathrm{Na}_{2} \mathrm{SiO}_{3}\right.$, Fluka), respectively. The properties of the commercial dispersants used in the experimental studies are shown in Table 1.

\subsection{Experimental Program}

The procedures followed to determine the suitable dispersant type and optimum dispersant ratio for ESC-3 clay slurries are as a flow chart in Fig. 1. More detailed explanations about the experimental studies were given belong to Mucur (2010) [28] in the master thesis.

\subsubsection{Preparation of Slip Casting Slurry and Flow Tests}

Because the final test samples exhibited an $\sim 10 \%$ shrinkage after casting the clay-containing suspension, the dimensions of bar samples formed by the mould were designed to be $10 \%$ larger $\left(13.2 \times 3.2 \times 1.25 \mathrm{~cm}^{3}\right)$. The casting slurry used to determine the flow behavior was obtained by mixing ESC-3 clay and tap water to give a $60 \mathrm{wt}$ \% solid ratio using a mechanical mixer (WiseStir, MS 1000, at $800 \mathrm{rpm}$ ) for 20 minutes. After that, the sieve residue and the amount of solid ESC-3 slurry were calculated to be $9.61 \%$ and $59.76 \%$ using a $63 \mu$ sieve. The weight of the liter was determined to be $159.3 \mathrm{~g} / \mathrm{L}$. The dispersant was added to the sieved part of the slurry in controlled amounts. The mixtures were prepared by mixing at $800 \mathrm{rpm}$ for 15 minutes in a beaker at a medium temperature measured to be $27 \pm 1^{\circ} \mathrm{C}$. Flow times for the slurry were measured in the presence of different dispersants. By using a stopwatch, the first flow time was recorded in seconds, and after this, the mouth of the Ford cup was closed with a tap. The slurry was poured into the Ford cup again, and after keeping it for 30 minutes, the second flow time was recorded in seconds (see Fig. 2).

To determine the optimum slip casting conditions (optimum dispersant type and dispersant dosage), flow curves were created for the different dispersant dosages. The thixotropy (\%) value was calculated using Eq. 1 [27]. As a result of the calculations, curves showing the thixotropy-dosage relationships were drawn.

$$
\text { Thixotropy }(\%)=\frac{\text { Flow time } 2(\mathrm{~s})-\text { Flow time } 1(\mathrm{~s})}{\text { Flow time } 2(\mathrm{~s})} \times 100
$$

Table 1. Properties of Commercial Dispersants

\begin{tabular}{|c|c|c|c|c|c|}
\hline Properties & Dolapix SPC 7 & Dolapix PC-67 & Darvan 821A & Darvan CN & $\mathrm{Na}_{2} \mathrm{SiO}_{3}$ \\
\hline $\begin{array}{l}\text { Molecular weight } \\
\text { (g/mol) }\end{array}$ & 7000 & 7000 & 3500 & 15000 & 122.063 \\
\hline Chemical basis & $\begin{array}{l}\text { Silicate- } \\
\text { polycarbonate }\end{array}$ & $\begin{array}{l}\text { Polycarboxylic } \\
\text { acid }\end{array}$ & $\begin{array}{l}\text { Ammonium } \\
\text { polyacrylate }\end{array}$ & $\begin{array}{l}\text { Ammonium } \\
\text { polymethacrylate }\end{array}$ & \\
\hline Physical state & Yellowish liquid & $\begin{array}{l}\text { Yellowish- } \\
\text { brown liquid }\end{array}$ & $\begin{array}{l}\text { Pale yellow } \\
\text { liquid }\end{array}$ & Liquid & Colorless \\
\hline Active matter & approx. $45 \%$ & approx. $43 \%$ & $40 \%$ & $25 \%$ & - \\
\hline Solubility & Water-miscible & Water-miscible & Highly soluble & - & - \\
\hline $\begin{array}{l}\text { Specific gravity at } \\
20^{\circ} \mathrm{C}\left(\mathrm{g} / \mathrm{cm}^{3}\right)\end{array}$ & approx. 1.45 & approx. 1.30 & 1.08 to 1.14 & 1.041 & 1.37 \\
\hline $\mathrm{pH}\left(\right.$ at $\left.25^{\circ} \mathrm{C}\right)$ & approx. 13.0 & approx. $8.0^{*}$ & 7.0 to $8.0^{*}$ & 7.5 to $9.0^{\dagger}$ & $12.31^{*}$ \\
\hline
\end{tabular}

$* 1 \%$ solution $\dagger 5 \%$ solution $* 25 \%$ solution 
Characterization of ESC-clay<smiles>C1=CC2CCCC(C1)C2</smiles>

Preparing plaster mold<smiles>C1=CC2CCC1C2</smiles>

Slurry preparation with ESC-3 clay<smiles>C1=CC2CCC1C2</smiles>

Determination of suitable dispersant type and optimum dispersant ratio for ESC-3 slurry in the presence of

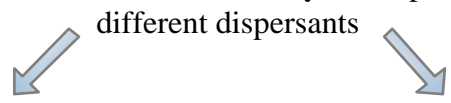

$\mathrm{pH}$ and $\mathrm{ZP}$ measurement of clay suspension depending on Dolapix PC-67 dosage
Forming with slip casting method

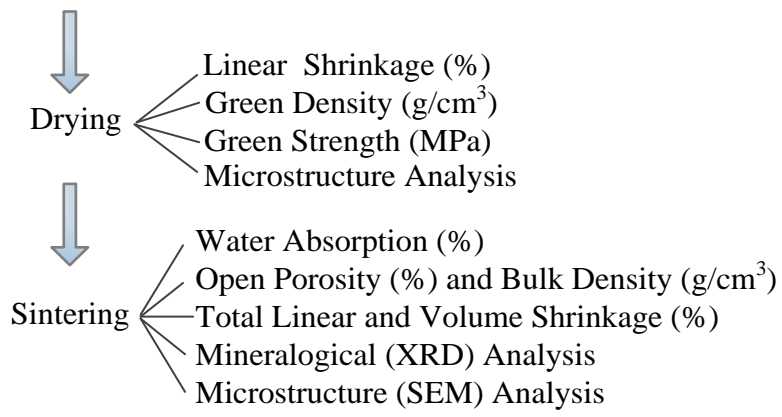

Figure 1. Shematic Diagram of the Experimental Program

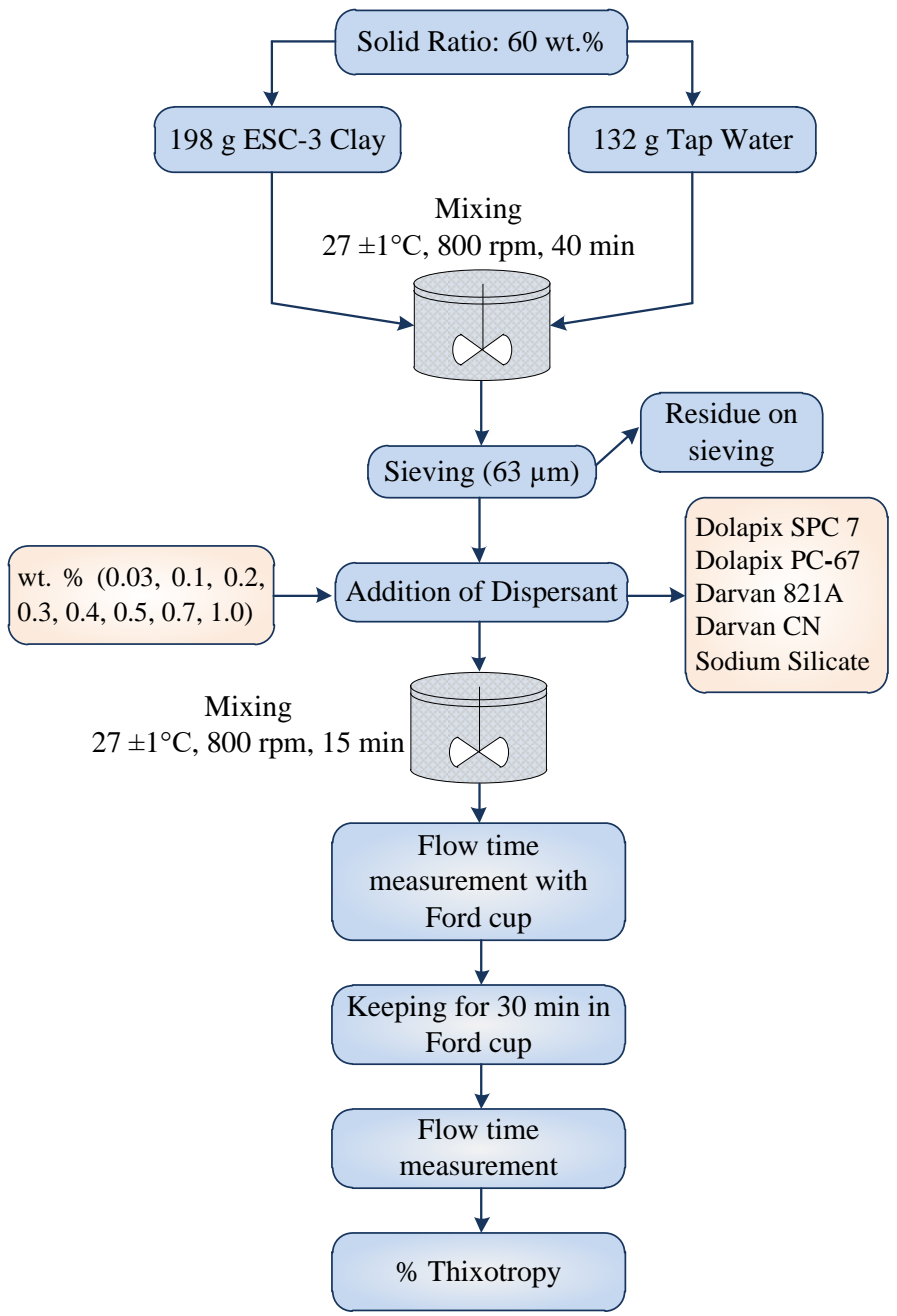

Figure 2. Process Steps for Determining the Ford Cup Flow Time in the Presence of Dispersants 


\subsubsection{Forming ESC-3 Slurry using the Slip Casting Method}

The dispersant (Dolapix PC-67) was selected using the curves obtained from flow time and thixotropy measurements, and the slurry was prepared according to the process steps with different dosages: $0 \%, 0.03 \%, 0.1 \%$ and $1 \mathrm{wt} . \%$ of the selected dispersant - shown in Fig. 3 and then shaped in plaster moulds. After the forming process, 10 pieces of products were obtained using each dosage of the dispersant. The photos in Fig. 4 shows flow test of the slurry with a Ford Cup, slip casting of the slurry and measuring the dimensions of the bar shaped sample after casting, respectively.

\subsubsection{Zeta Potential Measurements based on the Dispersant Concentration in the Clay Suspension}

Ten grams per liter of Dolapix PC-67 stock solution was prepared before performing $\mathrm{pH}$ and zeta potential (ZP) measurements that depend on the dispersant concentration in the clay suspensions. Tap water was used to simulate the working conditions in the ceramic industry. ZP measurements related to dispersant concentration in the clay suspensions were recorded by a Zetameter (Zeta Sizer Nano ZS Model, Malvern, UK). To prepare the desired dispersant concentrations, a sufficient amount of the solution was taken from the stock solution and added to 1 $\mathrm{g}$ of ESC-3 clay to give a total volume of $100 \mathrm{~mL}$. The prepared suspensions were then mixed in a magnetic stirrer for 15 minutes at room temperature (RT). A $0.75 \mathrm{~mL}$ sample was then taken from the suspension of a known $\mathrm{pH}$ and injected into the zeta measurement cell. All measurements were performed at $27 \pm 1^{\circ} \mathrm{C}$. The tap water used had a $\mathrm{pH}$ of 7.5 to 7.9 and a conductivity of $1117 \mu \mathrm{mhos} / \mathrm{cm}$. Mobility of the particles was converted into ZP using the Smoluchowski equation given below $[17,38]$ :

$$
\mathrm{U}=\frac{\zeta \varepsilon_{\mathrm{r}} \varepsilon_{0}}{\eta}
$$

where $U$ is the electrophoretic mobility, $\varepsilon_{\mathrm{r}}$ is the permittivity of the medium, $\varepsilon_{0}$ is the permeability of a vacuum $\left(8.854 \times 10^{-12}\right.$ $\left.\mathrm{C}^{2} / \mathrm{Jm}\right), \eta$ is the viscosity of the medium (Poise) and $\zeta$ is the ZP.

\subsection{Drying and Sintering Process}

The green products taken from the plaster mould were dried for three days at RT $\left(23 \pm 1^{\circ} \mathrm{C}\right)$. The dried products were sintered in a Protherm PLF 150-5 model high-temperature oven up to $1200^{\circ} \mathrm{C}$ for 1 hour at a heating rate of $10^{\circ} \mathrm{C} / \mathrm{min}$. The final products were obtained by cooling at the same rate.

\subsubsection{Green Sample Testing}

After the forming process, various tests were carried out to determine the linear drying shrinkage (\%), green density and green strength (three-point bending test) of the dried green products. Average values were calculated by using five samples for each dosage. The diagonal lengths of bar samples were measured at RT before $\left(\mathrm{L}_{0}\right)$ and after drying $\left(\mathrm{L}_{1}\right)$. The linear drying shrinkage $(\%)$ was calculated with the equation given below:

$$
\text { Linear Drying Shrinkage (\%) }=\frac{\mathbf{L}_{\mathbf{0}}-\mathbf{L}_{\mathbf{1}}}{\mathbf{L}_{\mathbf{0}}} \times 100 \%
$$

The masses (m) and volumes (V) of bar samples removed from the plaster mould were measured and their densities $\left(\mathrm{g} / \mathrm{cm}^{3}\right)$ were calculated. Three-point bending tests of bar-shaped samples were performed with a Thermodynamic brand TC20-200 model.
In addition to these physical tests, a small amount of dried samples was powdered, dried at $60^{\circ} \mathrm{C}$ and then coated with carbon. SEM images were obtained to observe microstructural changes.

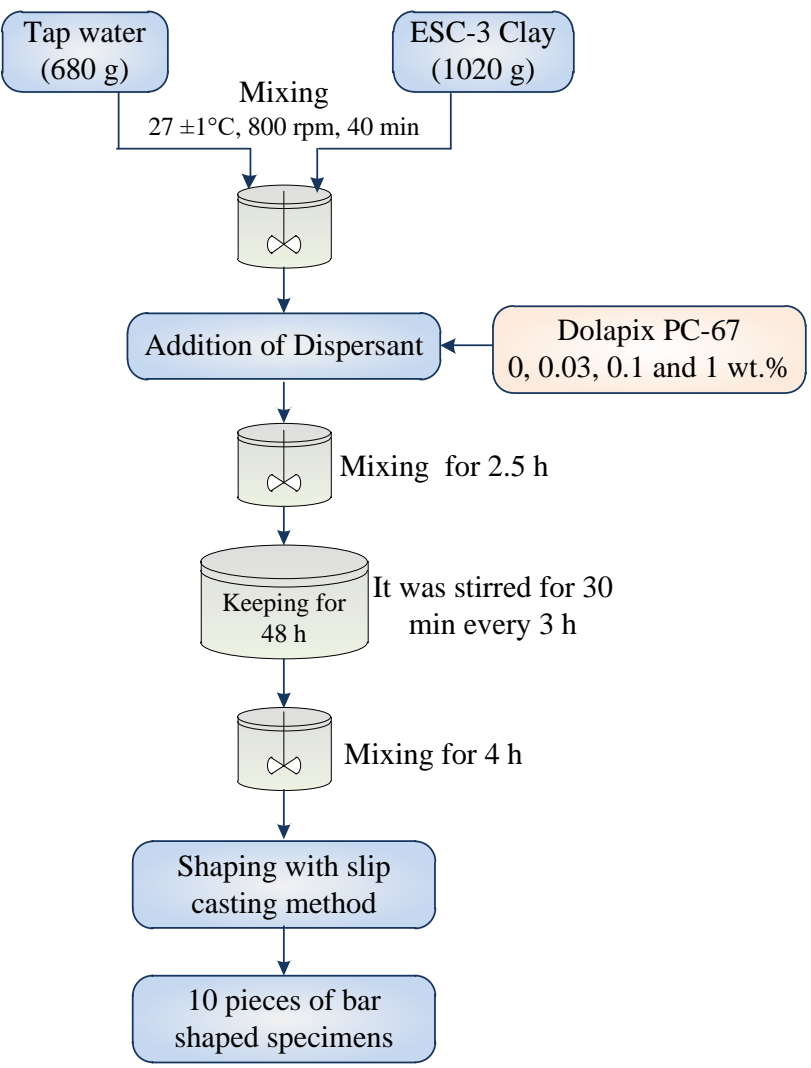

Figure 3. Process Steps for Forming ESC-3 Slurry Based on Dolapix PC 67 Dosage

\subsubsection{Sintered Sample Testing}

The physical, mineralogical and microstructural properties of fired samples with added Dolapix PC-67 at 0\%, 0.03\%, 0.1\% and $1 \mathrm{wt} . \%$ amounts were determined. First, the total linear shrinkage $(\%)$, total shrinkage volume (\%), open porosity (vol. \%), water absorption (wt. \%) and bulk densities $\left(\mathrm{g} / \mathrm{cm}^{3}\right)$ were measured. Three-point bending tests, as well as XRD and SEM analyses, were performed. The test results of five sintered samples for each dosage were averaged. After samples were sintered, the total linear shrinkage $(\%)$ values were calculated with Eq. 3 given in Section 3.4.1. Total shrinkage volume $(\%)$ values were calculated by Eq. 4 below:

$$
\text { Total Shrinkage Volume }(\%)=\frac{\mathrm{v}_{2}-\mathrm{v}_{1}}{\mathrm{v}_{1}} \times 100 \%
$$

where $V_{1}$ is the initial volume calculated after drying, while $V_{2}$ is the volume calculated after sintering. Mechanical tests were carried out as in the case of the green strength tests.

Moisture in the sintered samples was removed to determine open porosity and bulk density values for the material. Firstly, the samples were dried in the oven until they reached a constant weight. All dry samples $\left(\mathrm{M}_{\text {dry }}\right)$ were placed in a water bath after being weighed so that they were completely covered by the water which was then boiled for 4 hours. After that, they were kept in water for 24 hours. The thin water film layer on the sample surfaces was removed with a cloth before being weighed $\left(\mathrm{M}_{\mathrm{wet}}\right)$ or wet weighing. Lastly, the masses of the samples in water were 

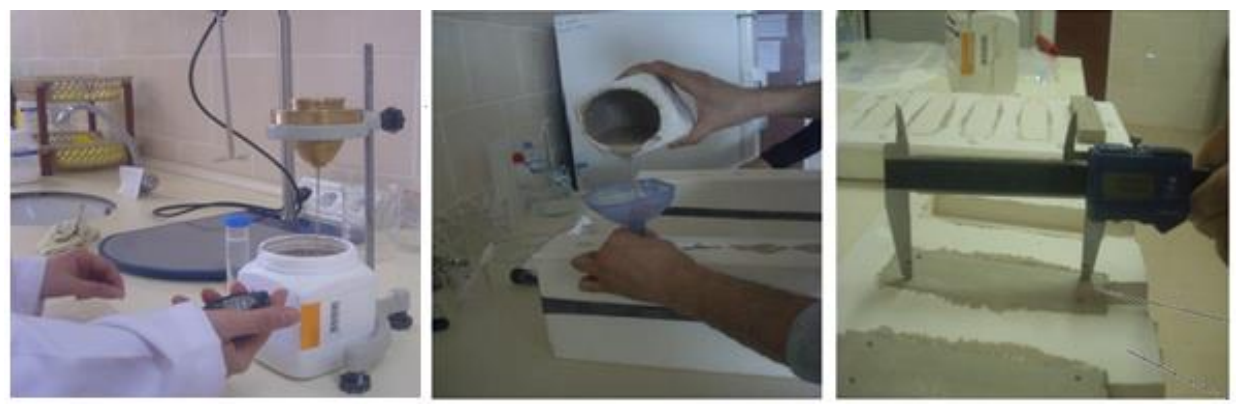

Figure 4 (a) Flow Test of the Slurry with a Ford Cup (b) Slip Casting of the Slurry (c) Measuring the Dimensions of the Bar Shaped Sample after Casting

measured on an Archimedes balance (MS). Open porosity (vol. $\%$ ), water absorption (wt. \%) and bulk density values $\left(\mathrm{g} / \mathrm{cm}^{3}\right)$ were determined by using the equations below $\left(\rho_{\text {water }}=1 \mathrm{~g} / \mathrm{cm}^{3}\right)$ :

Water Absorption (wt. \%) $=\frac{M_{\text {wet }}-M_{\text {dry }}}{M_{\text {dry }}} \times 100 \%$

Porosity (vol. \%) $=\frac{\mathrm{M}_{\mathrm{wet}}-\mathrm{M}_{\mathrm{dry}}}{\mathrm{M}_{\mathrm{wet}}-\mathrm{M}_{\mathrm{S}}} \times 100 \%$

Bulk Density $\left(\mathrm{g} / \mathrm{cm}^{3}\right)=\frac{\mathrm{M}_{\mathrm{dry}}}{\mathrm{M}_{\mathrm{wet}}-\mathrm{M}_{\mathrm{S}}} \times 100 \%$

Powdered sintered samples were sieved to below $100 \mu \mathrm{m}$, and XRD and SEM analyses of samples with added dispersant were also performed.

\section{Results and Discussion}

\subsection{Chemical, Mineralogical, Physical and Thermal Analyses}

The chemical and mineralogical compositions of ESC-3 clay were obtained by X-ray fluorescence (XRF) and X-ray diffraction (XRD). These analyses are given in Table 2 and Fig. 5, respectively. From the XRD pattern of the raw sample, the major phases of albite $\left(\mathrm{NaAlSi}_{3} \mathrm{O}_{8}\right)$ and quartz $\left(\mathrm{SiO}_{2}\right)$ were found with their most intense peak at $27.89^{\circ}$ and $26.63^{\circ}$ respectively, while the less intense peaks of other phases were identified as kaolinite $\left(\mathrm{Al}_{2} \mathrm{Si}_{2} \mathrm{O}_{5}(\mathrm{OH})_{4}\right)$ and illite $\left(\mathrm{K}_{0.7} \mathrm{Al}_{2}(\mathrm{Si}, \mathrm{Al})_{4} \mathrm{O}_{10}(\mathrm{OH})_{2}\right)$.

TG-DTA analyses results for ESC-3 clay are shown in Fig. 6. When examining TG-DTA analyses, the endothermic DTA peak observed between 50 and $130^{\circ} \mathrm{C}$, and the corresponding $\sim 1.7 \%$ mass loss in the TG curve, indicated that the sample lost its physical water. It was seen that the mass loss observed in the TG curve continued with increasing temperature, but there were no intense endothermic peaks in the DTA curve. This mass loss continued up to $425^{\circ} \mathrm{C}$ and the mass loss between 125 and $425^{\circ} \mathrm{C}$ was due to the removal of water more tightly bonded to the structure. Thus, the mass loss in the first step was $4.12 \%$. There were also quartz and albite phases in the raw material used in addition to kaolinite and illite. The reason for the difference between the TG and DTA curves may be that the raw material contains different phases. It can be said that the second DTA peak and its mass loss occurring from 425 to $650^{\circ} \mathrm{C}$, indicated the transformation of kaolinite $\left(\mathrm{Al}_{2} \mathrm{O}_{3} \cdot 2 \mathrm{H}_{2} \mathrm{O}+2 \mathrm{SiO}_{2}\right)$ to metakaolinite $\left(\mathrm{Al}_{2} \mathrm{O}_{3} \cdot 2 \mathrm{SiO}_{2}+2 \mathrm{H}_{2} \mathrm{O}+\right.$ Energy) by losing its structural hydroxyls.
As indicated in published literature, the transformation of quartz to $\alpha$-quartz at $573^{\circ} \mathrm{C}$ gives a very weak endothermic peak. However, this weak peak is not seen due to the large endothermic peak formed as a result of clay minerals losing crystalline water at this temperature $[27,29]$. The transformation reactions of kaolinite and quartz are given below:

$$
\begin{aligned}
& \text { Kaolinite } \stackrel{500-550^{\circ} \mathrm{C}}{\longrightarrow} \text { Metakaolinite } \\
& \text { Quartz } \stackrel{573^{\circ} \mathrm{C}}{\longrightarrow} \alpha \text {-quartz } \stackrel{870^{\circ} \mathrm{C}}{\longrightarrow} \alpha \text {-tridymite }
\end{aligned}
$$

It is known from the published literature that illite produces endothermic peaks at $100^{\circ} \mathrm{C}$ and $600^{\circ} \mathrm{C}$, indicating the removal of physical and structural hydroxyls from the body [27-29].

Table 2. Chemical composition, particle size and surface area of

\begin{tabular}{|c|c|}
\hline Oxides & (wt.\%) \\
\hline $\mathrm{SiO}_{2}$ & 56.27 \\
\hline $\mathrm{Al}_{2} \mathrm{O}_{3}$ & 21.23 \\
\hline $\mathrm{Fe}_{2} \mathrm{O}_{3}$ & 4.38 \\
\hline $\mathrm{Na}_{2} \mathrm{O}$ & 2.72 \\
\hline $\mathrm{Cr}_{2} \mathrm{O}$ & 2.09 \\
\hline $\mathrm{CaO}$ & 1.31 \\
\hline $\mathrm{K}_{2} \mathrm{O}$ & 0.89 \\
\hline $\mathrm{TiO}_{2}$ & 0.55 \\
\hline $\mathrm{MgO}$ & 0.27 \\
\hline $\mathrm{P}_{2} \mathrm{O}_{5}$ & 0.18 \\
\hline $\mathrm{MnO}$ & 0.09 \\
\hline *Other oxides & 0.26 \\
\hline Ignition loss (at $1000^{\circ} \mathrm{C}$ for $2 \mathrm{~h}$ ) & 9.50 \\
\hline Total oxides & 99.86 \\
\hline \multicolumn{2}{|l|}{ Particle diameters $(\mu \mathrm{m})$} \\
\hline$d_{10 \%}$ & 2.02 \\
\hline $\mathrm{d}_{50 \%}$ & 9.27 \\
\hline $\mathrm{d}_{90 \%}$ & 60.94 \\
\hline Specific surface area $\left(\mathrm{m}^{2} / \mathrm{g}\right)$ & 11.89 \\
\hline
\end{tabular}
the ESC-3 clay

*SrO; $\mathrm{ZrO}_{2} ; \mathrm{CuO} ; \mathrm{NiO} ; \mathrm{CoO} ; \mathrm{ZnO} ; \mathrm{Rb}_{2} \mathrm{O}$ 


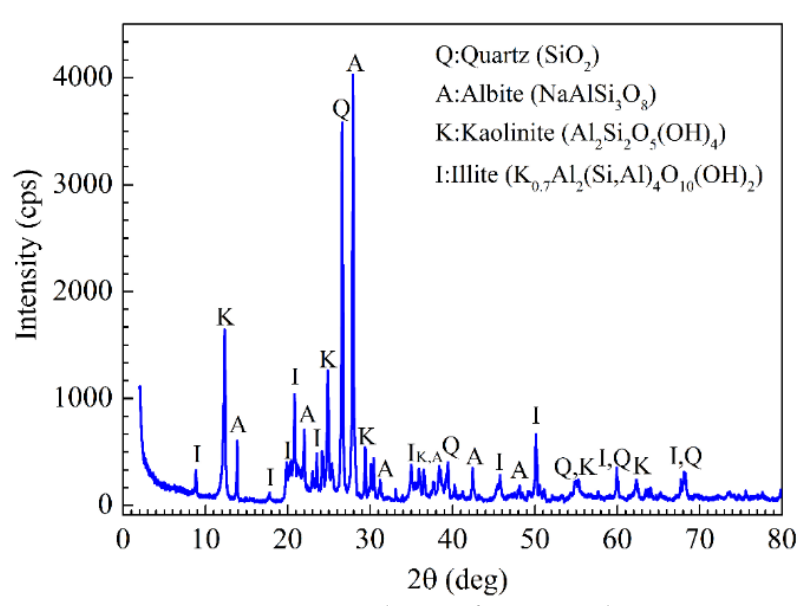

Figure 5. XRD analysis of ESC-3 clay

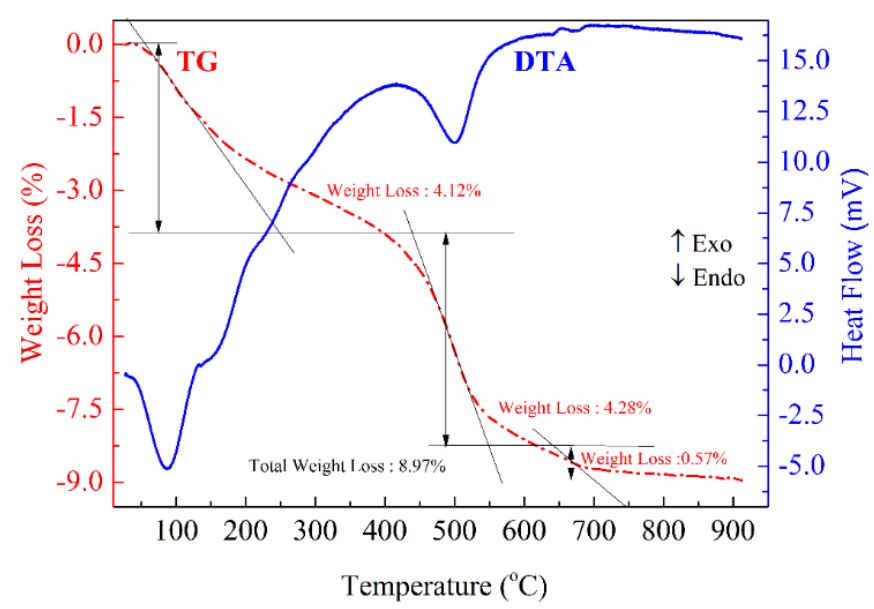

Figure 6. The TG and DTA Curves of ESC-3 Clay

\subsection{The Effect of Various Dispersant Types and Dosages on the Flow of Slurry and the Determination of Optimum Slip Casting Conditions}

Flow and thixotropy curves were drawn to optimize the dispersion and flow conditions of slurries prepared using ESC-3 clay with 60 wt. \%, and the results are shown in Fig 7. As seen in Fig 7 (a), both inorganic (SS) and polymeric dispersants considerably reduced the flow time of the suspensions. The lowest flow times for other dispersants, except for $\mathrm{Na}_{2} \mathrm{SiO}_{3}$, were observed at a dispersant dosage of $0.1 \mathrm{wt}$. \%. The flow times for $\mathrm{Na}_{2} \mathrm{SiO}_{3}$, Darvan CN, Darvan A821, Dolapix SPC 7 and Dolapix PC-67 at this dosage were 47, 32, 35, 31 and 28 seconds, respectively. However, flow times increased beyond a certain dispersant dosage.

As seen in Fig. 7 (b), thixotropy was the highest at 0.1 and a 0.3 wt. $\%$ dispersant dosage but decreased at other dosages. In fact, this result is not compatible with the flow time curves. In other words, thixotropy is expected to be lowest in concentration where fluidity is highest (shortest flow time). This is because thixotropy is defined as a temporary decrease in the stability of the slurry and the formation of a network structure in the slurry. Therefore, the formation of this network structure would be expected when its fluidity was at its lowest, but this did not happen. In a study performed by Akpinar (2019) [14], it was determined that the thixotropy of the cordierite suspensions decreased with increasing Darvan A821. In another study related to the sanitary ware ceramic slurry, the effect of $\mathrm{NaCO}_{3}$ and
$\mathrm{Ca}(\mathrm{OH})_{2}$ on the slip casting behavior of slurry was examined, and it was observed that the increase in the dispersant amount did not cause a significant change in thixotropy. It was determined that the thixotropy value changed between 30 and $33 \%$. No significant relationship was established between viscosity and thixotropy. At a dispersant dosage of $0.1 \mathrm{wt} \%$, the thixotropy values of $\mathrm{Na}_{2} \mathrm{SiO}_{3}$, Darvan $\mathrm{CN}$, Darvan A821, Dolapix SPC 7 and Dolapix PC-67 were $41.25 \%, 38.46 \%, 52.05 \%, 46.55 \%$ and $21.67 \%$, respectively [20].

$\mathrm{Na}_{2} \mathrm{SiO}_{3}$ - an inorganic dispersant - reduces the flow time of ESC-3 slurry by an electrostatic stabilization mechanism. This electrostatic stabilization can be explained by three mechanisms [31-33]: (i) $\mathrm{Na}_{2} \mathrm{SiO}_{3}$ hydrolyzes in water and multivalent anionic silicate compounds such as $\left[\mathrm{Si}_{2} \mathrm{O}_{3}(\mathrm{OH})_{4}\right]^{2-}$ and $\left[\mathrm{SiO}_{2}(\mathrm{OH})_{4}\right]^{4-}$ form. These anions are adsorbed to positively charged centers on the surface edge of the clay, making the total negative charge and zeta potential even more negative. Thus, electrostatic repulsion increases between clay particles, which increases stability and reduces fluidity. (ii) These multivalent anions can exchange an ion with structural $\mathrm{OH}^{-}$ions on the edge. These structural $\mathrm{OH}^{-}$ions can increase the number of negative edge charges. As a result, particles repel each other, that is, they are deflocculated. (iii) When clay minerals are in the water, flocculating cations such as $\mathrm{Ca}^{2+}$ and $\mathrm{Mg}^{2+}$ can pass into the water. Such cations can cause flocculation and impaired stability. As seen in the reaction below, anionic silicate ions - coming from $\mathrm{Na}_{2} \mathrm{SiO}_{3}$ in the medium - then form insoluble silicate compounds such as $\mathrm{CaSiO}_{3}$ with divalent charged cations which then precipitate, thereby eliminating the negative effect of these cations on stability.

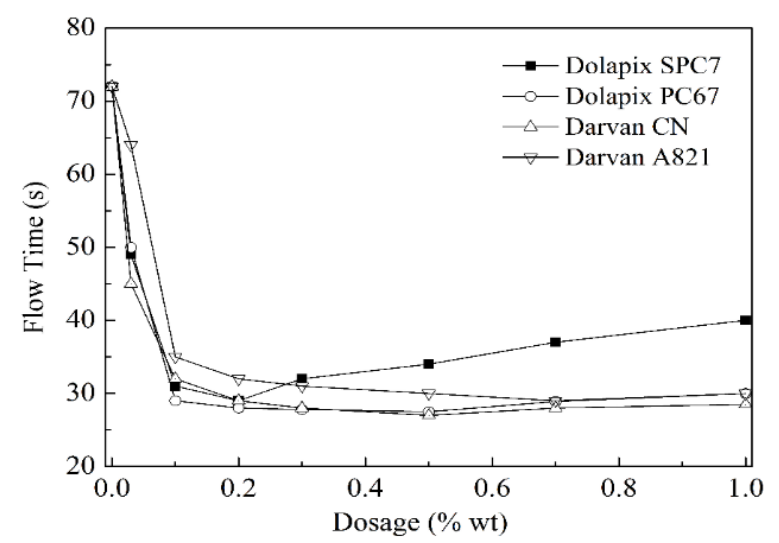

(a)

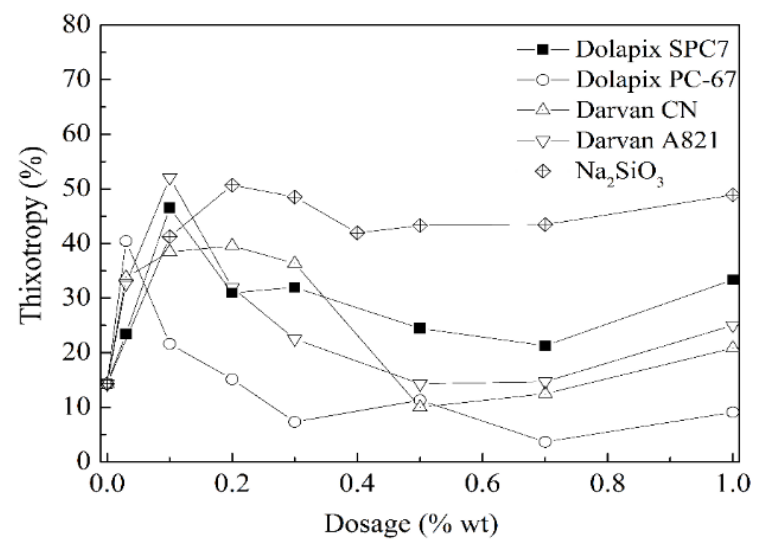

(b)

Figure 7. (a) Flow Times (b) Thixotropy Values (Solid Ratio: 60 wt. \%, T: $27 \pm 1{ }^{\circ} \mathrm{C}$, Mixing Rate: $800 \mathrm{rpm}$ ) for Different Dispersants and Dosages in ESC-3 Slurry 


$$
\text { Ca-Kaolin }+\mathrm{Na}_{2} \mathrm{SiO}_{3} \longrightarrow \text { Na-Kaolin }+\frac{\mathrm{CaSiO}_{3}}{\text { insoluble }}
$$

The underlying mechanisms that polymer-based dispersants (Dolapix SPC 7, Dolapix PC-67, Darvan A821, Darvan CN) use to increase the stability of clay slurry and decrease the flow time are both electrostatic and steric stabilization mechanisms $[35,36]$. Therefore, the reason that organic dispersants are more effective in increasing both stability and fluidity compared to inorganic dispersant is that they can perform both steric and electrostatic stabilization simultaneously. Similar results were also found in the studies in published literature performed on different ceramic slurries [3, 17, 18, 20-22, 36-38]. Based on these findings, effective polymer dispersants for reducing flow times were Dolapix PC-67, Dolapix SPC 7, Darvan A821 and Darvan CN, respectively. The effective dispersants for decreasing thixotropy were determined to be Dolapix PC-67, Darvan CN and Dolapix SPC 7, respectively. According to these results, the optimum dispersant for the casting process was Dolapix PC-67. For the optimum dosage, $0.1 \mathrm{wt}$. $\%$ produced the lowest flow time.

\subsection{The pH and ZP of Clay Suspensions based on the Dolapix PC-67 Concentration}

The $\mathrm{pH}$ is an important parameter for all colloidal suspensions in terms of both surface formation and flow properties $[10,39,40]$. Therefore, $\mathrm{pH}$ measurements were made to determine whether there was a $\mathrm{pH}$ change in the slurry proportional to the dispersant concentration. Tap water was used in experiments to achieve similar working conditions to the ceramic industry. As seen in Fig 8, the $\mathrm{pH}$ of the clay suspension was $\sim 7.8$ in the environment without any dispersant and it increased gradually with the addition of Dolapix PC-67. These $\mathrm{pH}$ values are close to the $\mathrm{pH}$ values of the dispersants (see Table 1).

ZP measurements in the presence of Dolapix PC-67 are shown in Fig. 7. The ZP value of the suspension was $-31.5 \mathrm{mV}$ before the addition of Dolapix PC-67 and it was seen that first, there was a decrease with increasing Dolapix PC-67 concentration and then the $\mathrm{ZP}$ value decreased to approximately $-28 \mathrm{mV}$ at a concentration of $0.05 \mathrm{~g} / \mathrm{L}$. It was seen that $\mathrm{ZP}$ increased after 0.1 $\mathrm{g} / \mathrm{L}$. The highest $\mathrm{ZP}$ value $(-45.1 \mathrm{mV})$ was achieved at $1 \mathrm{~g} / \mathrm{L}$ and after this dosage, ZP remained almost constant. Anionic polymer molecules formed by water ionization of the polycarboxylic based polymer were adsorbed to both positively charged centers on the clay surface edges in the sample and to positively charged centers of other minerals (quartz and albite), thereby increasing the negative ZP values of particles. An anion exchange mechanism with $\mathrm{OH}^{-}$groups on the surface also played a role when the polymers were adsorbed to particle surfaces. The adsorption mechanism has been discussed in published literature studies where different clay minerals and different polymeric dispersants have been used. This mechanism is explained by the formation of a cationic linkage and anion exchange between metallic cations in clays and the negatively charged centers of the polymer [2, 26, 41-44].

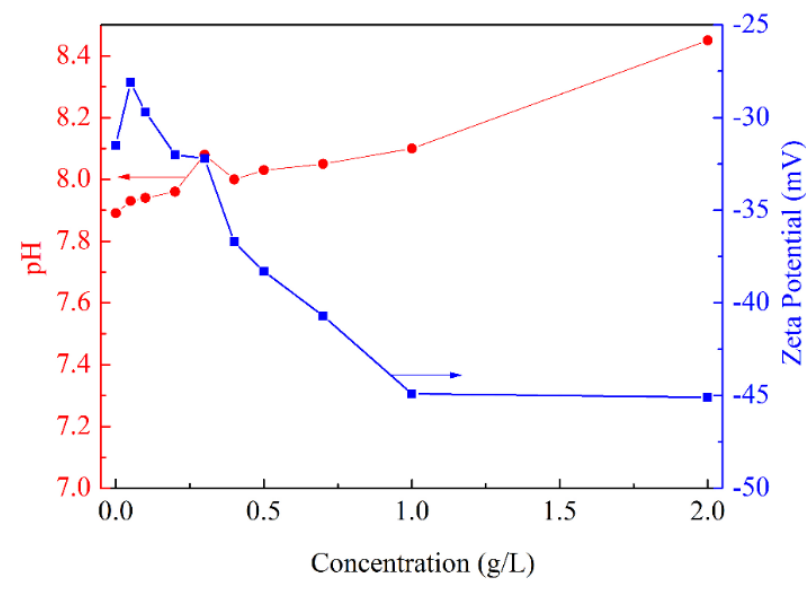

Figure 8. $p H$ and $\mathrm{ZP}(\mathrm{mV})$ Changes According to Dolapix PC-67 Concentration in the ESC-3 Clay Suspension: $1 \mathrm{~g}$ clay, $100 \mathrm{~mL}$ tap water and at $27 \pm 1^{\circ} \mathrm{C}$

As seen from the ZP curve, it is not possible for the ZP of particles to increase beyond a certain dispersant concentration. This shows that dispersant concentration plays an important role in achieving the stability of suspensions, which is also supported by the flow curves.

\subsection{The Effect of Dolapix PC-67 Dosage on the Properties of Green Bodies}

\subsubsection{Physical and Mechanical Properties}

Slip casting was performed for suspensions prepared with different dosages $(0,0.03,0.1$ and 1 wt. \%) of Dolapix PC-67. The effect of dispersant dosage on the physical properties on the green bodies obtained is shown in Fig. 9.

The linear drying shrinkage of the additive-free sample was $4.82 \%$. It was observed that there was a decrease in the shrinkage value beyond $0.03 \mathrm{wt} . \%$ and it decreased to approximately $4 \%$ at the optimum dispersant dosage $(0.1$ wt. \%). Beyond this dosage, the decrease was relatively slow. At the highest dosage (1 wt. \%), the shrinkage value was $3.2 \%$. As seen from published literature, one of the desired parameters when forming with the slip casting process is to have minimum linear drying shrinkage [1]. It has been determined in the published literature that there is no linear relationship between dry shrinkage values in green products from sanitary ware slurry with $\mathrm{NaCO}_{3}$ and $\mathrm{Ca}(\mathrm{OH})_{2}$. Eygi and Ateşok (2008) [21] determined that dry and sintered shrinkage values of the products obtained from kaolin slurries were independent of the dispersant type but found out that polymeric dispersants achieved higher dry and sintered shrinkage than sodium silicate. In this present study, it was determined that the dry shrinkage values obtained with a 67 to $70 \mathrm{wt} . \%$ amount of solid in the presence of different dispersants changed between 0.90 and $1.70 \%$. In addition, the amount of dry shrinkage of a sanitary ware product produced in the Güral Vit Company was 5.8\% and this value was found to be quite high compared to the amounts of dry shrinkage obtained in this study. 


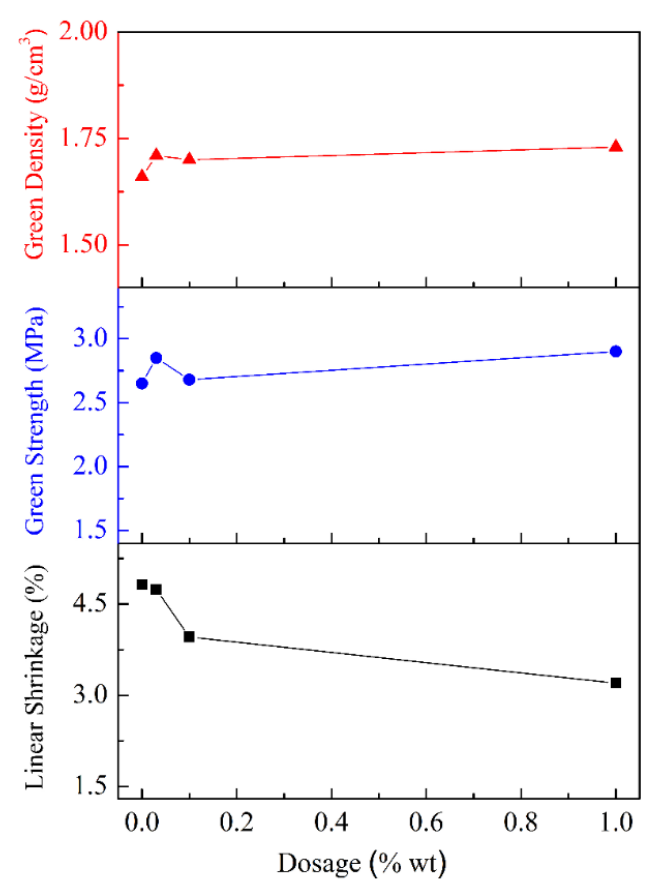

Figure 9. Linear Drying Shrinkage, Green Density and Green Strength Curves of Green Bodies Obtained from ESC-3 Casting Slurry Prepared at Different Dolapix PC-67 Dosages

As seen in Fig. 9, the green density of the additive-free sample was $1.66 \mathrm{~g} / \mathrm{cm}^{3}$, the density increased to $1.71 \mathrm{~g} / \mathrm{cm}^{3}$ at a dosage of $0.03 \mathrm{wt} . \%$ and then remained almost constant. As a result, the addition of dispersant had a positive effect on the density of the green body. In the published literature, a study examining the relationship between the density of a product obtained by dispersant type and dosage, and its green density, was performed by Mei et al. (2003) [4]. The study concentrated on the slurries made from cordierite-based glass ceramics and it was revealed that there was a linear relationship between the viscosity curves obtained based on dispersant concentration and green densities, and the conditions achieving the lowest viscosity also had the best results in terms of green density. Moreover, it was stated that among polymeric dispersants, Duramax D-3021, Targon 1128, Tiron and Dolapix CE-64 and the polycarboxylic acid-based Dolapix CE-64 were effective in reducing ZP and viscosity. It was determined that it yielded the best result by producing a more packed and homogeneous microstructure. SEM images also supported these results. It was stated that performance differences between polymeric dispersants were closely related to hydrocarbon chain lengths, the hydrophilic/hydrophobic ratio of its molecular structure and orientation to the particle surface. All these differences affected the electrostatic and electrosteric stabilization strength of dispersants. It was also determined in the same study that the densities of green bodies obtained from cordierite-glass slurry prepared using 0.2 to $1 \mathrm{wt}$. \% dosages with all dispersants showed little increase compared to the dosage of other dispersants, except for Dolapix CE-64. The increase for Dolapix CE-64 was more effective in increasing the density.

It is seen in Fig. 9, the green strength of the additive-free sample was $2.65 \mathrm{MPa}$, and it increased to $2.85 \mathrm{MPa}$ at a dosage of 0.03 wt. $\%$. At 0.1 wt. $\%$, it decreased $(2.70 \mathrm{MPa})$ and then increased to $2.90 \mathrm{MPa}$ at a dosage of $1 \mathrm{wt}$. \%. The results show similar behavior with the green density curve. Therefore, because the stability and fluidity of the green product obtained from additive-free ceramic slurry was lower than that of the product with Dolapix PC-67, the packing of the slurry on the plaster mould surface was also weaker. This reduced the strength a little. However, there was a difference in flow curves with respect to the dispersant dosage. The $0.1 \mathrm{wt} \% \%$ dosage, which yielded the lowest viscosity, did not give the best results in terms of green strength and density. On the contrary, the best results were obtained at 0.03 wt. \%. In a published literature study conducted with inorganic dispersants, it was determined that the strength of the green product obtained from clay slurry using $\mathrm{NaCO}_{3}$ additive increased in accordance with the dispersant dosage [20]. For example, the green strength, which was $25.11 \mathrm{~kg} / \mathrm{cm}^{2}$ at 0.06 wt. $\%$ of sodium carbonate, increased to $26.87 \mathrm{~kg} / \mathrm{cm}^{2}$ at 0.07 wt. \%, and it was $27.43 \mathrm{~kg} / \mathrm{cm}^{2}$ at 0.085 wt. \%. However, it was observed that these results did not have a linear relationship to the viscosity data. In the same study, it was determined that $\mathrm{Ca}(\mathrm{OH})_{2}$ increased dry and sintered body strength more than $\mathrm{NaCO}_{3}$. All these results reveal that the lowest viscosity (the best fluidity) conditions for clay slurry do not always provide the best conditions in terms of green product properties. Another outcome is that the rheology of slurries and their relationship to the product properties is much more complex than expected.

\subsubsection{Microstructural Properties}

The purpose of SEM analysis was to observe that the green products obtained from slurry prepared with different Dolapix PC-67 dosages were more homogeneous and tightly packed. However, there was no significant difference between the SEM images (Fig. 10 a-d). The study by Mei et al. (2003) [4] examined SEM images of green products obtained from cordierite-glass ceramic slurry prepared with different dispersant types by slip casting. It was seen that the product obtained with the dispersant achieving the best fluidity had a much more homogeneous microstructure and packing. The layered structures of clays make homogeneous packing difficult compared to minerals that have a spherical or spherical-like particle structure. This may create difficulties in monitoring the microstructural differences between additive-free slurry and slurry with added dispersant.

\subsection{The effect of Dolapix PC-67 Dosage on the Properties of Sintered Product}

\subsubsection{Physical and Mechanical Properties}

Fig. 11 shows water absorption (\%), open porosity (\%) and bulk densities of sintered samples obtained by adding Dolapix PC-67 to the ESC-3 slurry at four different dosages. While the water absorption of the additive-free sample was $16.72 \%$, it suddenly dropped to $2.45 \%$ at $0.03 \mathrm{wt}$. $\%$. When the dosage was increased from 0.1 to $1 \mathrm{wt} \%$, water absorption increased from $3.34 \%$ to $3.39 \%$.

While the open porosity of the additive-free samples was $27.23 \%$, it decreased significantly to $4.36 \%$ at 0.03 wt. $\%$. Open porosity increased slightly at $0.1 \mathrm{wt}$. $\%$ dosage, to $5.86 \%$. It became $5.83 \%$ at $1 \mathrm{wt} . \%$. According to the results obtained, less porosity occurred in the sintered products because the addition of dispersant increased the stability of the slurry and accordingly increased the packing and density, which in turn reduced the water absorption value. Şakar and Deliormanl1 (2004) [20] determined that the structures obtained with $\mathrm{Ca}(\mathrm{OH})_{2}$ added to the sanitary ware slurry had a lower water absorption value than those obtained with $\mathrm{NaCO}_{3}$ as the additive. The water absorption value of sanitary ware produced in Güral Vit was $0.5 \%$, which was less than those of the products obtained in this study. 


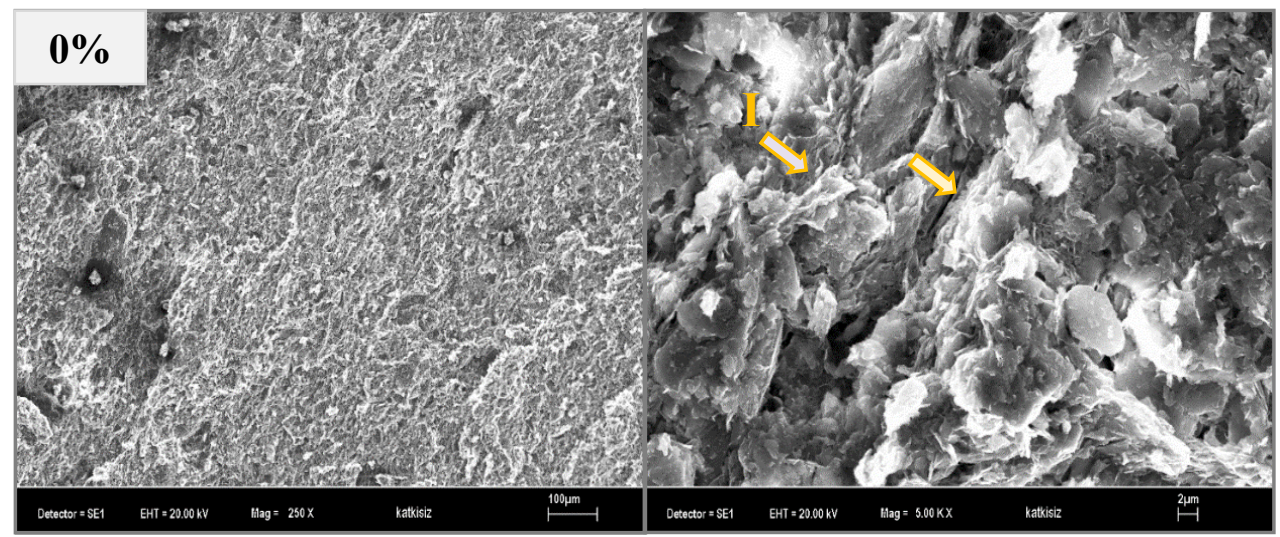

(a)

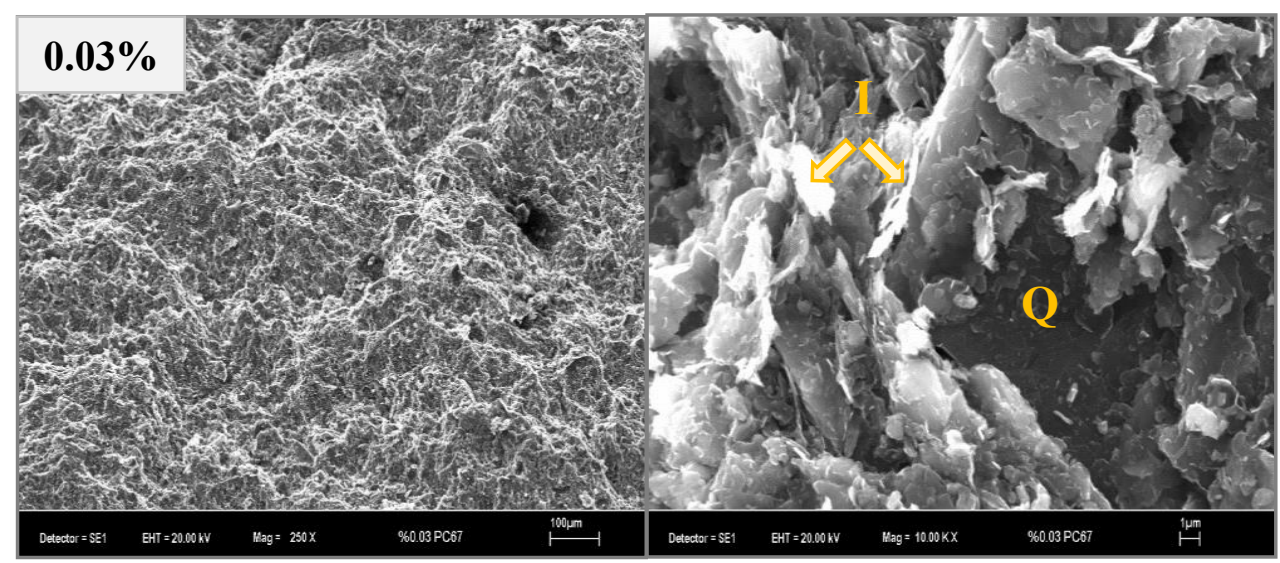

(b)

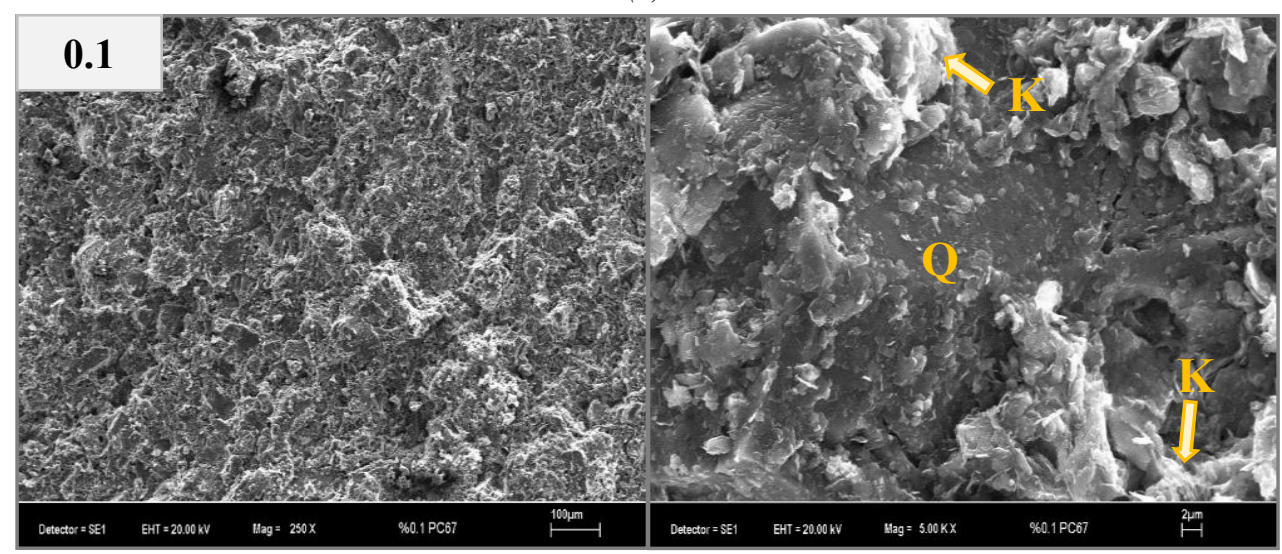

(c)

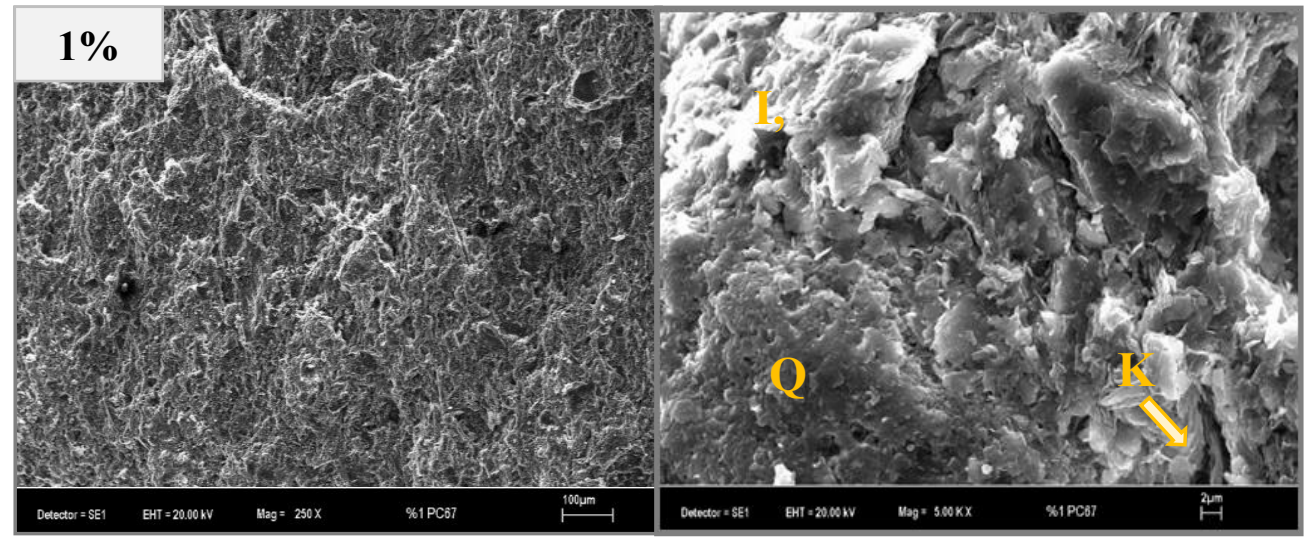

(d)

Figure 10. SEM Images of Green Bodies Obtained from ESC-3 Casting Slurry Prepared at Different Dolapix PC-67 Dosages (I: illite, $K$ : kaolinite, $Q:$ quartz) (a) $0 \%(250$ and $5 K \times)$ (b) $0.03 \%(250$ and $10 K \times)$ (c) $0.1 \%(250$ and $5 K \times)$ (d) $1 \%\left(250\right.$ and $\left.5 K^{\times}\right)$ 
As seen in Fig. 11, the bulk density of additive-free samples increased from $1.63 \mathrm{~g} / \mathrm{cm}^{3}$ to $1.78 \mathrm{~g} / \mathrm{cm}^{3}$ by showing a significant increase at 0.03 wt. $\%$. At the $0.1 \mathrm{wt} . \%$ optimum dosage, the bulk density was $1.75 \mathrm{~g} / \mathrm{cm}^{3}$ and at $1 \mathrm{wt} . \%$, it was $1.72 \mathrm{~g} / \mathrm{cm}^{3}$. It is seen that the results obtained were compatible with the porosity and water absorption values. Density increased as porosity decreased. However, beyond the 0.3 wt. \% dispersant dosage, there was no significant effect on the bulk density of the sintered product.

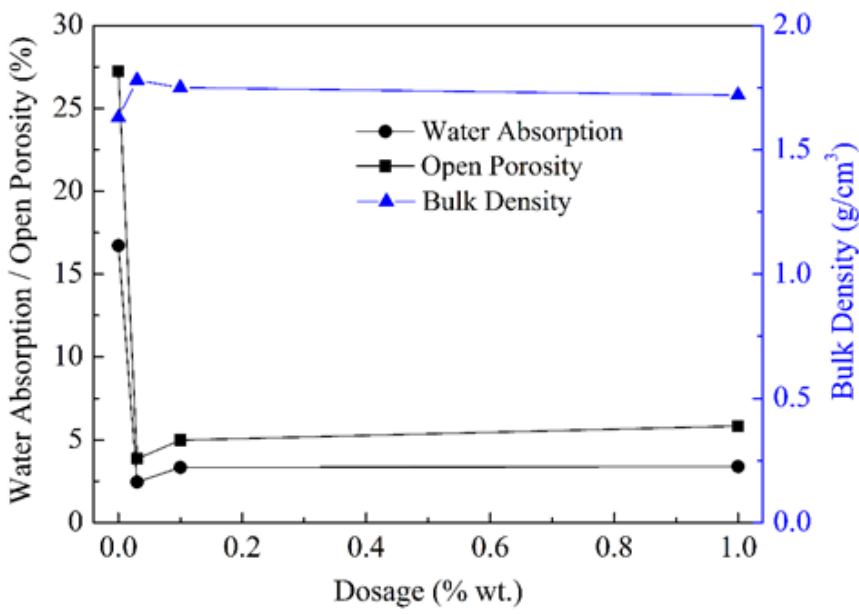

Figure 11. Water Absorption, Apparent Porosity and Bulk Density Results of Sintered Products Obtained from ESC-3 Casting Slurry Prepared with Different Dolapix PC-67 Dosages

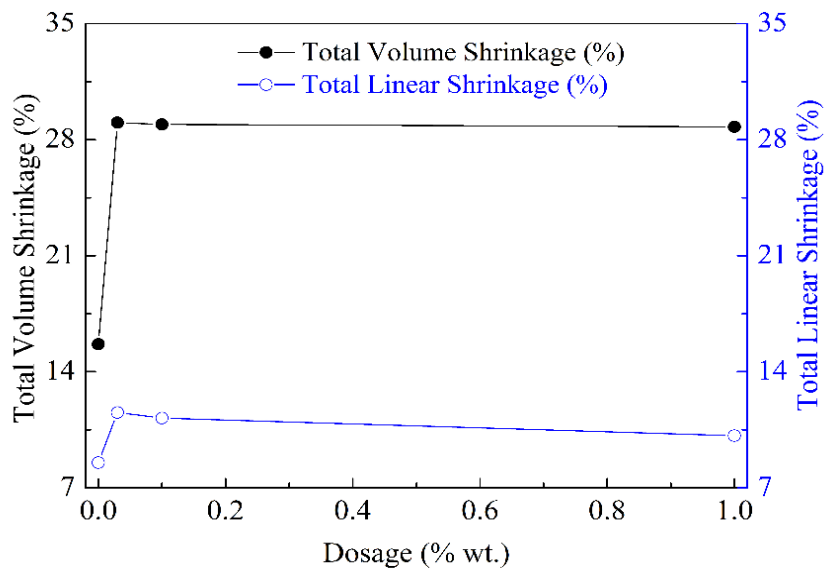

(a)

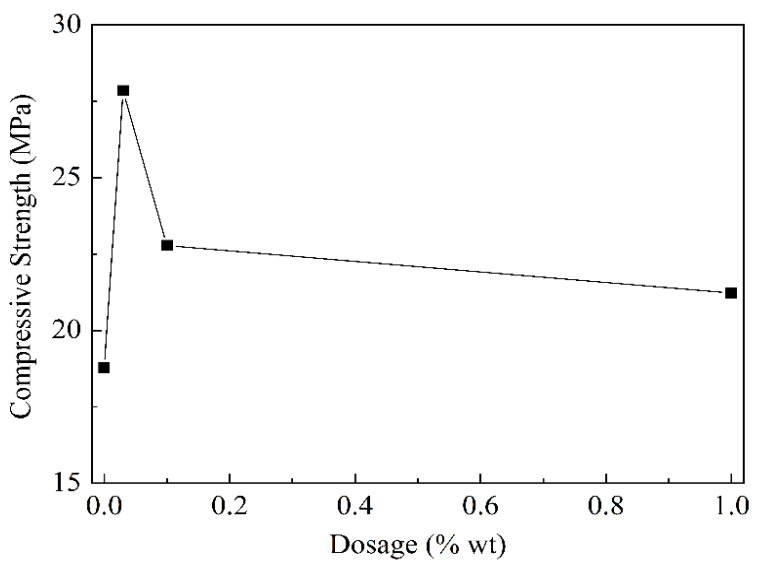

(b)

Figure 12. (a) Total Volume and Linear Shrinkage (b) Strength Results of Sintered Products Obtained from ESC-3 Casting Slurry Prepared at Different Dolapix PC-67 Dosages
As seen in Fig. 12 (a), while the total linear and volume shrinkage values of additive-free samples were $8.52 \%$ and $15.66 \%$, they were $11.53 \%$ and $29.03 \%$ at 0.03 wt. \%, respectively. It was seen that the volume shrinkage values increased significantly. At the optimum dosage ( $0.1 \mathrm{wt} \%$ ), they were $11.20 \%$ and $28.92 \%$, respectively. The total linear and volume shrinkage of samples with $1 \mathrm{wt}$. \% additive were $10.14 \%$ and $28.78 \%$, respectively, and no significant change was observed. These curves were also compatible with water absorption/porosity and bulk density (Fig. 11) curves, and the shrinkage values remained constant beyond a dosage of 0.03 wt. $\%$, similar to other physical properties.

Eygi and Ateşok (2008) [21] determined that the total shrinkage of kaolin slurry did not differ significantly with respect to the dispersant type, but the bodies obtained from polyelectrolyte-added slurry were subject to less shrinkage. In the study by Şakar-Deliormanlı and Yayla (2004) [20], it was seen that the total and dry shrinkage of the sanitary ware slurry was independent of the dispersant type and viscosity change. Tsetsekao et al. (2001) [3], on the other hand, measured linear shrinkage values of the sintered products obtained from alumina by the slip casting technique using Darvan C, Duramax D 3500 and Dolapix CE-64 dispersants. They stated that the dispersant type was moderately effective in linear firing shrinkage (\%) and determined the shrinkage value to be $10.5 \%$ for Dolapix CE-64 alumina (60 wt. \% solid).

It is seen in Fig. 12 (b) that the compressive strength of the additive-free sample was $18.78 \mathrm{MPa}$, and this value increased to $27.85 \mathrm{MPa}$ at 0.03 wt. $\%$ of Dolapix PC-67. At the dosages of 0.1 and $1 \mathrm{wt} . \%$, the strength values were measured to be $22.78 \mathrm{MPa}$ and $21.25 \mathrm{MPa}$, respectively. According to these results, the mechanical strength results for the optimum dispersant dosage determined from the flow curves are not the same. However, it is clearly seen that samples with added Dolapix PC-67 achieved better results than additive-free samples. The reason for this is that the slurry was more stable in the presence of the dispersant and the green density was higher as a result of better particle packing. Şakar-Deliormanlı and Yayla (2004) [20] measured the bending strength of the fired product obtained from sanitary ware casting slurry in the presence of $\mathrm{Ca}(\mathrm{OH})_{2}$ and $\mathrm{Na}_{2} \mathrm{CO}_{3}$ at $1250^{\circ} \mathrm{C}$. It was determined that the bodies obtained from $\mathrm{Ca}(\mathrm{OH})_{2}$ slurry had higher strength. They stated that this result was in accordance with the flow curves, i.e., $\mathrm{Ca}(\mathrm{OH})_{2}$ added slurry had low viscosity.

\subsubsection{XRD Analysis Results}

XRD analyses of the sintered bodies prepared from additivefree and slurries with added dispersant were performed (Fig. 13). The phases in sintered products were quartz, anorthite and mullite. It was observed in Fig. 13 that the intensity of the quartz peak in the additive-free body decreased with the addition of dispersant. The reason for this was that the slurry was more closely packed because it was more homogeneous in the added-dispersant dispersed additive environment. Thus, quartz particles reacted with anorthite or clay during firing to form mullite, and thus the intensity of the quartz peak decreased. It is known that mullite forms as a result of the direct phase transformation of kaolinite. On the other hand, the albite (see Fig. 5) within the body of the ESC-3 clay melts at $1200^{\circ} \mathrm{C}$, having a glassy phase and, therefore, the albite peaks disappear. Illite in the clay is subjected to dehydroxylation at temperatures beyond $950{ }^{\circ} \mathrm{C}$ [44] and its crystalline structure changes. 


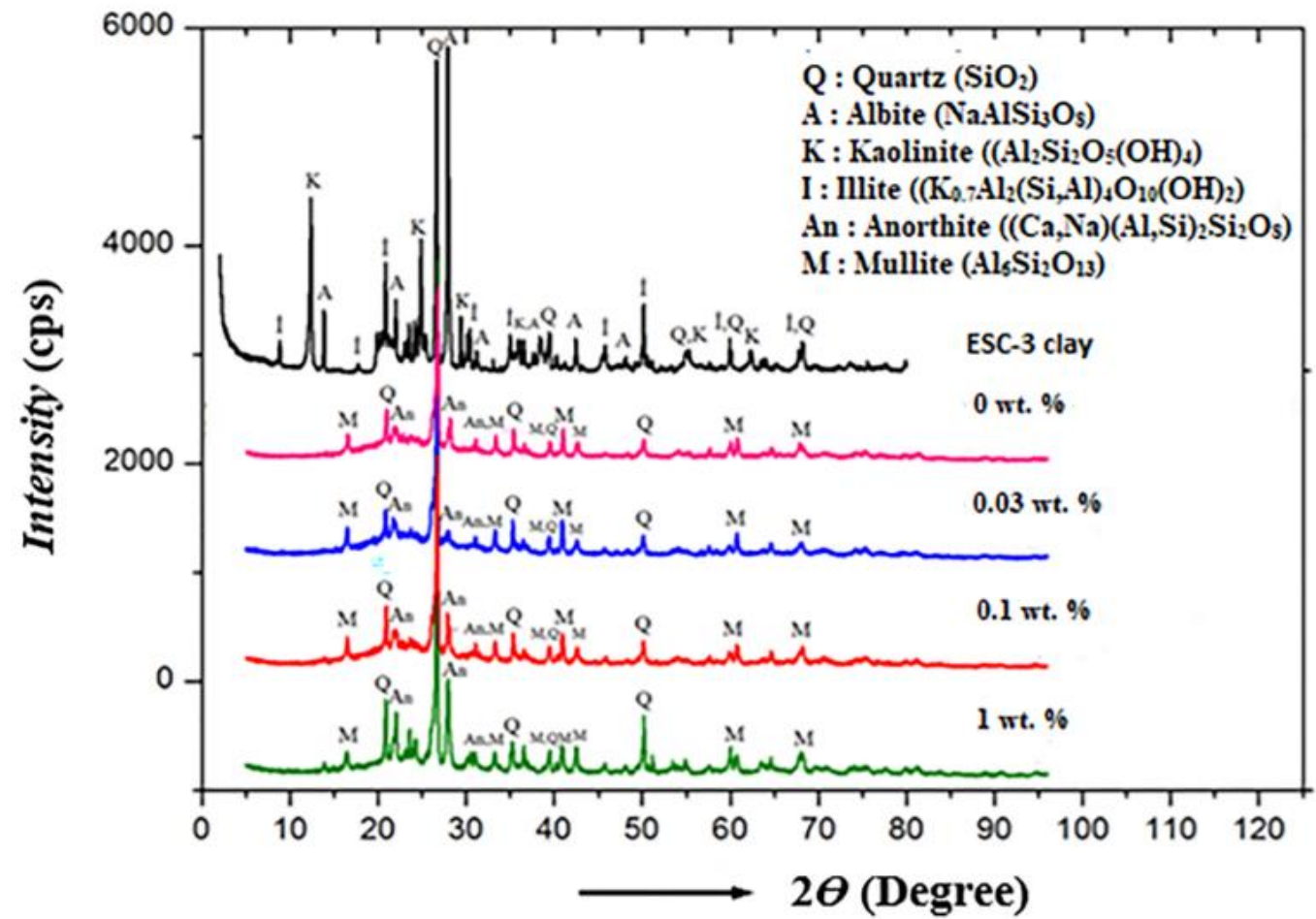

Figure 13. XRD Pattern of Sintered Products Obtained from ESC-3 Casting Slurry Prepared at Different Dolapix PC-67 Dosages

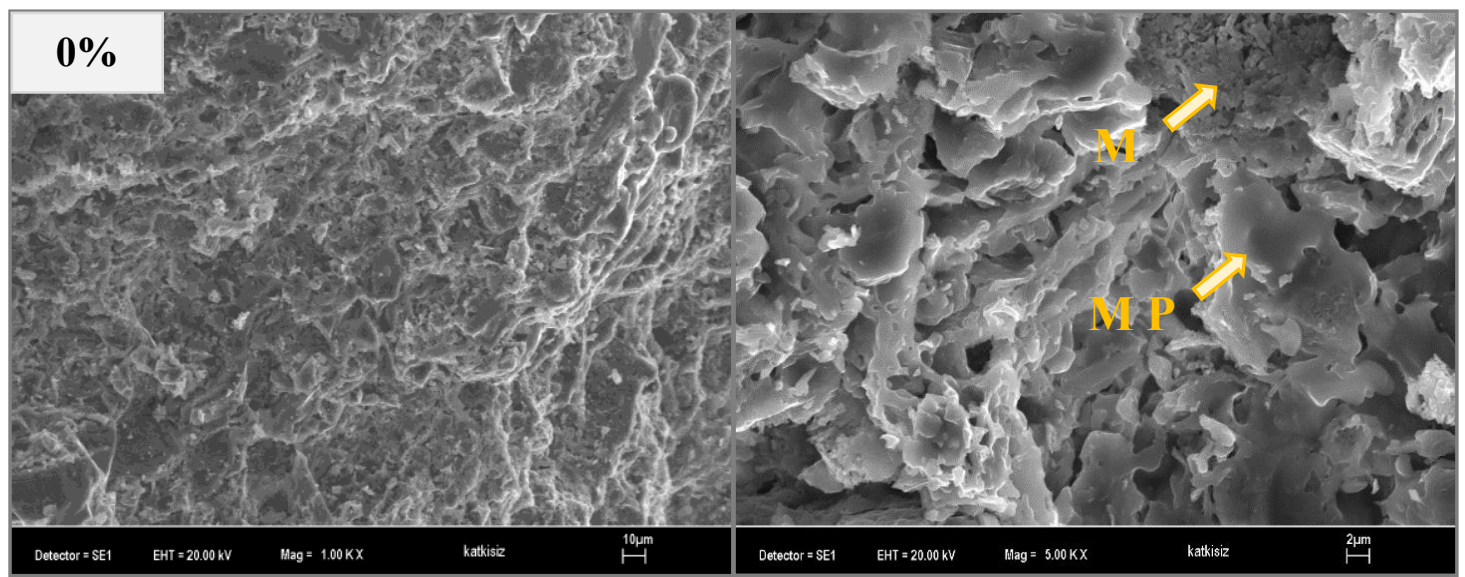

(a)

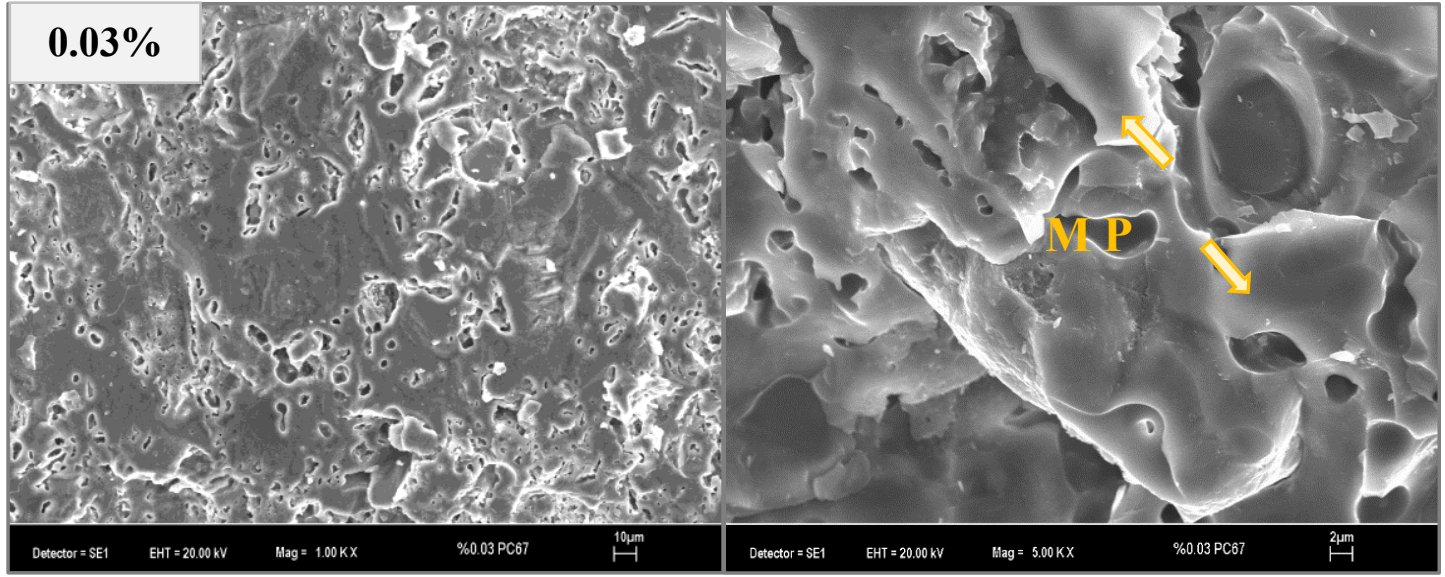

(b) 


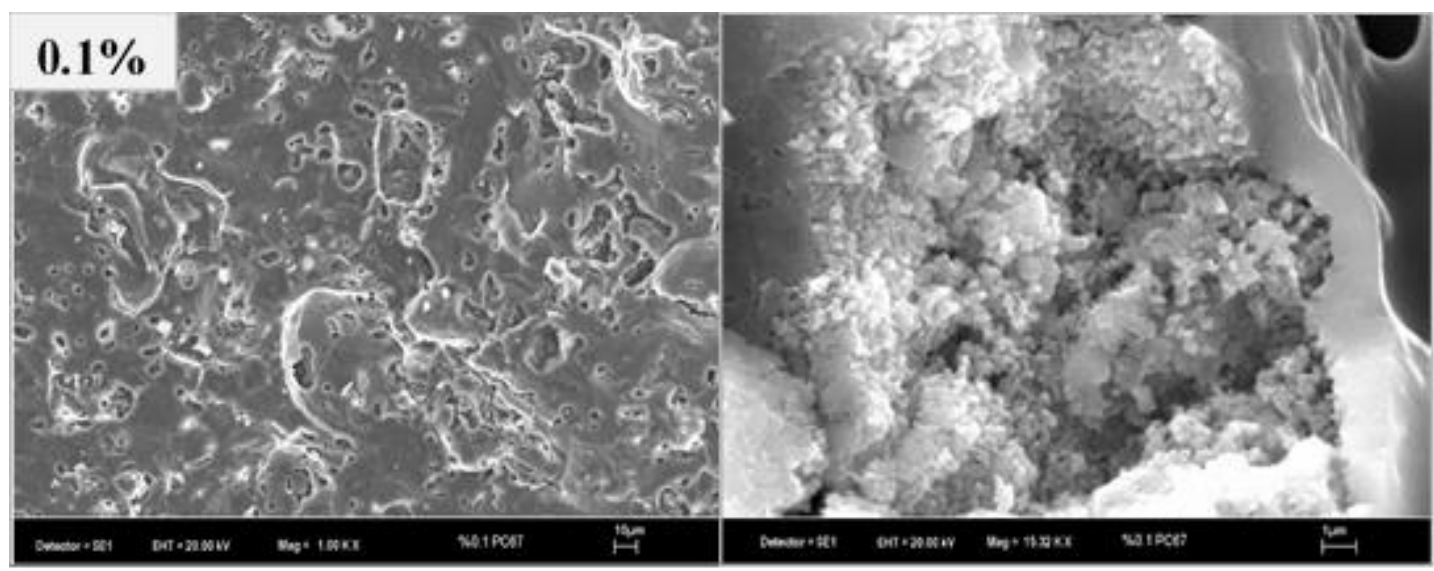

(c)

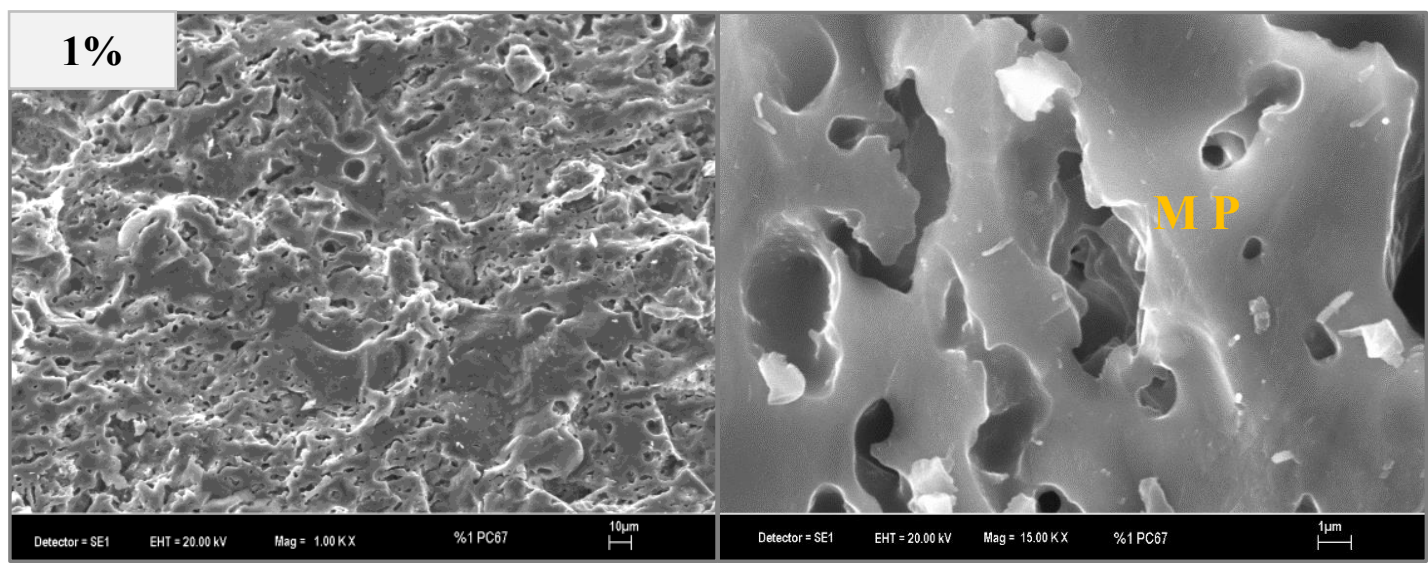

(d)

Figure 14. SEM Analysis of Sintered Samples Obtained from ESC-3 Casting Slurry Prepared at Different Dolapix PC-67 Dosages, (M: mullite, M P: molten phase) (a) $0 \%(1 \mathrm{~K} \times$ and $5 \mathrm{~K} \times$ ) (b) $0.03 \%(1 \mathrm{~K} \times$ and $5 \mathrm{~K} \times)($ c) $0.1 \%(1 \mathrm{~K} \times$ and $15 \mathrm{~K} \times)(\mathrm{d}) 1 \%(1 \mathrm{~K} \times$ and $15 \mathrm{~K} \times$ )

According to SEM images of sintered products obtained from ESC-3 casting slurry prepared at the different Dolapix PC-67 dosages shown in Fig. 14, there are no significant differences in terms of homogenization and pore structure within the microstructures. However, considering the higher magnification of the SEM images, it can be said that the structure obtained from the ceramic slurry prepared at the optimum Dolapix PC-67 dosage had a more homogeneous structure compared to the additive-free samples and other structures. For example, when examining the SEM images of the additive-free body and the body with $1 \mathrm{wt} . \%$ dispersant, the structures are porous. This is due to the fact that the slurry is not homogeneous and stable enough. All other physical properties related to sintered products show that the addition of dispersant positively contributes both to these properties and homogenization. However, the results were not always consistent with dispersant dosages. In the published literature, there is a study directly related to the effect of dispersant dosage on the microstructure of ceramic slurry.

Mei et al. (2001) [26] examined the effect of Dolapix CE-64 dosage on the microstructure of the products obtained from cordierite-glass ceramic slurry and stated that the microstructure obtained at the optimum dosage - where the fluidity was minimum - was much more homogeneous, and the porosities resulting from flocculation were much less. Mei et al. (2003) [4], in another study carried out with cordierite-glass ceramic slurry, investigated the effect of dispersant type on the sintered product microstructure. They reported that Dolapix CE-64, which yielded the best results in terms of fluidity among the four different dispersants used in the study, also achieved the best results in terms of microstructure homogeneity.

\section{Conclusions}

- The addition of dispersant had a positive effect on the physical and mechanical properties of the green and fired products obtained by slip casting. The addition of dispersant increased the stability and packing of the slurry, and therefore increased the green density of the product, resulting in less porosity in the sintered product. This increased the mechanical strength by reducing water absorption.

- It is important to determine the optimum value of the dispersant dosage when preparing clay slurry using the slip casting method. However, it can be said - based on the flow curves obtained with the Ford cup and the properties of the green/fired product - that the optimum dispersant dosage, where the flow time is the lowest (the highest fluidity) in ceramic casting slurry does not mean that this condition is also 
optimum for the physical/mechanical properties of those same products.

- It is not always possible to use SEM analysis to reveal the relationship between the flow curve of the slurry and the physical/mechanical properties of green and sintered products obtained from slurry prepared at different dispersant dosages. This condition is affected by the layered structure of clay. Because of the formation of agglomeration or dispersion between clay particles, it does not achieve good results by considering samples prepared from suspensions containing spheres and formed by slip casting.

- Among the dispersants used, the optimum dispersant was determined to be polycarboxylic acid-based Dolapix PC-67, and the optimum dosage was found to be $0.1 \mathrm{wt}$. \% according to the flow curve. The sequence of the effectiveness of the dispersants in reducing the flow time can be listed as follows: Dolapix PC-67 > Dolapix SPC $7>$ Darvan 821A > Darvan $\mathrm{CN}>$ Sodium silicate.

- Linear shrinkage and mechanical strength values of the green products obtained with dispersant-free slurry were $4.82 \%$ and 2.65 $\mathrm{MPa}$, respectively, while these values were $3.96 \%$ and $2.68 \mathrm{MPa}$ in the green products obtained from the slurry prepared with 0.1 wt. \% of Dolapix PC-67. The total volume shrinkage and mechanical strength values of the sintered product prepared with dispersant-free slurry were $15.66 \%$ and 18.78 MPa, respectively, while these values were $28.92 \%$ and $22.78 \mathrm{MPa}$ in the green products obtained from slurry prepared with 0.1 wt. \% Dolapix PC-6.

\section{References}

[1] Kingery, W.D. (1960). Introduction to Ceramics, John Wiley \& Sons Inc., New York, USA.

[2] Reed, J.S. (1994). Principles of Ceramics Processing (second edition), John Wiley \& Sons Inc., New York, USA.

[3] Tsetsekou, A., Agrafiotis, C., Leon, I. \& Milias, A. (2001). Optimization of the Rheological Properties of Alumina Slurries for Ceramic Processing Applications Part II: Spray-Drying, J. Eur. Ceram. Soc. 21, 493-506.

[4] Mei, S., Yang, J. \& Ferreira, J.M.F. (2003). Comparison of Dispersants Performance in Slip Casting of CordieriteBased Glass-Ceramics, Ceram. Int. 29, 785-791.

[5] Hotta, Y., Omura, N., Sato, K. \& Watari, K. (2007). Slip Casting Using Wet-Jet Milled Slurry, J. Eur. Ceram. Soc., 27, 753-757.

[6] Demirkol, N. (2019). Sintering and Technological Properties of Dry Pressed Ceramic Body Containing Kastamonu Mud and Clay, Europan Jounal of Science \& Techonology 15, 499-504.

[7] Sun, X., Wu, H., Zhu, G., Shan, Y. N., Xu, J., Li, J. \& Olevsky, E. (2020). Direct Coarse Powder Aqueous Slip Casting and pressureless Sintering of Highly Transparent AlON Ceramics, Ceram. Int. 46, 4850-4856.

[8] Xu, Y., Mao, X., Fan, J., Li, X., Feng, M., Jiang, B., Leia, F., \& Zhang, L. (2017). Fabrication of Transparent Yttria Ceramics by Alcoholic Slip-Casting, Ceram. Int. 43, 8839-8844.

[9] Shanefield, D.J. (1996). Organic Additives and Ceramic Processing (second edition), Kluwer Academic Publishers, Boston, USA.
[10] Dinger, D.R. (2002). Rheology for Ceramics - Dinger Ceramic Consulting Service, Clemson, USA.

[11] Landrou, G., Brumaud, C., Plötze, M. L., Winnefeld, F. \& Habert, G. (2018). A Fresh Look at Dense Clay Paste: Deflocculation and Thixotropy Mechanisms, Colloid Surfaces A. 539, 252-260.

[12] Rahaman, M.N. (1995). Ceramic Prosessing and Sintering, Marcel Dekkel Inc., New York, USA.

[13] Amorós, J.L., Beltrán, V., Sanz, V. \& Jarque, J.C. (2010). Electrokinetic and Rheological Properties of Highly Concentrated Kaolin Dispersions: Influence of Particle Volume Fraction and Dispersant Concentration. Appl. Clay Sci., 49, 33-43.

[14] Akpınar, S. (2019). Influence of Dispersing Agents on Microstructure-Related Properties of Slip Cast Cordierite Ceramics, Ceram. Int., 45, 15488-15495.

[15] Singer, F.S. (1963). Industrial Ceramics, Champman and Hall, London, England.

[16] Fangli, Y., Huanrui, W., Yu, B. \& Jianfeng, Y. (2010). Preparation and Characterization of Porous $\mathrm{Si}_{3} \mathrm{~N}_{4}$ Ceramics Prepared by Compression Molding and Slip Casting Methods, Bull. Mater. Sci., 33(5) 619-624.

[17] Greenwood, R. (2003). Review of the Measurement of Zeta Potentials in Concentrated Aqueous Suspensions using Electroacoustics, Adv. Coll. Inter. Sci., 106, 55-81.

[18] Gören, R., Ersoy, B., Özgür, C. \& Alp, T. (2012). Colloidal Stability-Slip Casting Behaviour Relationship in Slurry of Mullite Synthesized by the USP Method, Ceram. Int., 38, 679-685.

[19] Ganesh, I. (2011). Aqueous Slip Casting of $\mathrm{MgAl}_{2} \mathrm{O}_{4}$ Spinel Powder, Bull. Mater. Sci., 34 (2), 327-335.

[20] Şakar-Deliormanl1, A. \& Yayla, Z. (2004). Effect of Calcium Hydroxide on Slip Casting Behaviour, Appl. Clay Sci., 24, 237-243.

[21] Eygi, M.S. \& Ateşok, G. (2008). An Investigation on Utilization of Poly-Electrolytes as Dispersant for Kaolin Slurry and its Slip Casting Properties, Ceram. Int., 34, 1903-1908.

[22] Marco, P. \& Liorens, J. (2009). Surface Charge and Rheological Properties of Raw Porcelain Gres Suspension with Acrylic Bearing Carboxylic Groups, J. Eur. Ceram. Soc., 29, 559-564.

[23] Burgos-Montes, O. \& Moreno, R. (2007). Colloidal Behaviour of Mullite Powders Produced by Combustion Synthesis, J. Eur. Ceram. Soc., 274, 751-4757.

[24] Temoche, F., Garrido, L.B. \& Aglietti, E.F. (2005). Processing of Mullite-Zirconia Grains for Slip Cast Ceramics Slip Casting of Cordierite and Cordierite-Mullite Materials Ceram. Int. 31, 917-922.

[25] Camerucci, M.A., Cavalieri, A.L. \& Moreno, R. (1998). Slip Casting of Cordierite and Cordierite-Mullite Materials, J. Eur. Ceram. Soc., 18, 2149-2157.

[26] Mei, S., Yang, J. \& Ferreira, J. M. F. (2001). Effect of Dispersant Concentration on Slip Casting of CordieriteBased Glass Ceramics, J. Coll. Inter. Sci., 241, 417-421.

[27] Lao, X., Xu, X., Jiang, W., Liang, J., Miao, L. \& Wu, Q. (2020). Influences of Impurities and Mineralogical Structure of Different Kaolin Minerals on Thermal Properties of Cordierite Ceramics for High-Temperature Thermal Storage, Appl. Clay Sci., 187, 105485.

[28] Mucur, T. (2010). Optimisation of the Dispersion/Flowing Properties of Ball Clay used in 
Sanitary Ware Ceramic Productions and Its Influence on the Properties of Green and Fired Products, Afyon Kocatepe University, Institute for the Natural and Applied Sciences, Ms. Sc. Thesis.

[29] Grim, R.E. (1968). Clay Mineralogy (second edition), McGraw-Hill Book Comp, New York, USA.

[30] Karakaya, M. (2006). Properties and Identification Methods of Clay Minerals, Bizim Büro Basımevi, Ankara, Turkey.

[31] Leja, J. (1982). Surface Chemistry of Froth Flotation, Plenum Press, New York, USA.

[32] Huertas, F. J., Chou, L. \& Wollast, R. (1999). Mechanism of Kaolinite Dissolution at Room Temperature and Pressure Part II: Kinetic study, Geochim. Cosmochim. Acta, 63(19-20), 3261.

[33] Lagaly, G. (1989). Principles of Flow of Kaolin and Bentonite Dispersions, Appl. Clay Sci., 4, 105-123.

[34] Gregory, J. (1989). Fundamental of Flocculation, Crit. Rev. Environ. Control, 19, 185-230.

[35] Lagaly, G. \& Ziesmer, S. (2003). Colloid Chemistry of Clay Minerals: The Coagulation of Montmorillonite Dispersions Adv. Colloid Interface, 100-102, 105-128.

[36] Johnson, S. B., Franks G. V., Scales, P. J., Boger, D. V. \& Healy, T. W. (2000) Surface Chemistry-Rheology Relationships in Concentrated Mineral Suspensions Int. J. Miner. Process., 58, 267-304.

[37] Ferrari, B. \& Moreno, R. (1997). Electrophoretic Deposition of Aqueous Alumina Slips, J. Eur. Ceram. Soc., 17, 549-556.

[38] Tadros, T. T. (2005). Applied Surfactants, Principles and Applications, Wiley-VCH Verlag GmbH\&Co.KGaA, Weinheim

[39] Hunter, R. J. (1981). Zeta Potential in Colloid Science, Academic Press Inc., San Diego, USA.

[40] Çelik, M. S. \& Ersoy, B. (2004). In Schwarz, J. A., Contescu, C. I. \& K Putyera (eds), Mineral Nanoparticles: Electrokinetics: in Encyclopedia of Nanoscience and Nanotechnology (Marcel-Dekker Inc, New York) pp. 1991-2005.

[41] Chassagne, C., Mietta, F. \& Winterwerp, J. C. (2009). Electrokinetic Study of Kaolinite Suspensions, J. Coll. Inter. Sci., 336 352-359.

[42] Zaman, A. A., Tsuchiya, R. \& Moudgil, B. M. (2002). Adsorption of Low-Molecular-Weight Polyacrylic Acid on Silica, Alumina, and Kaolin J. Coll. Inter. Sci., 256 73-78.

[43] Taylor, M. L., Morris, G. E., Self, P. G. \& Smart, R. St. C. (2002). Kinetics of Adsorption of High Molecular Weight Anionic Polyacrylamide onto Kaolinite: The Flocculation Process, J. Coll. Inter. Sci., 250, 28-36.

[44] Ersoy, B., Evcin, A., Uygunoglu, T., Akdemir, Z. B., Brostow, W. \& Wahrmund, J. (2014). Zeta PotentialViscosity Relationship in Kaolinite Slurry in the Presence of Dispersants, Arab. J. Sci. Eng., 39, 5451-5457.

[45] Lavat, A. E., Grasselli, M. C. \& Julia, E. T. (2007). Phase Changes of Ceramic Whiteware Slip-Casting Bodies Studied by XRD and FT-IR, Ceram. Int., 33, 1111-1117. 